\title{
Purification of Matrix Gla Protein From a Marine Teleost Fish, Argyrosomus regius: Calcified Cartilage and Not Bone as the Primary Site of MGP Accumulation in Fish
}

\author{
DC SIMES, ${ }^{1}$ MK WILLIAMSON,${ }^{2}$ JB ORTIZ-DELGADO,${ }^{1}$ CSB VIEGAS,${ }^{1}$ PA PRICE, ${ }^{2}$ and ML CANCELA ${ }^{1}$
}

\begin{abstract}
Matrix Gla protein (MGP) belongs to the family of vitamin K-dependent, Gla-containing proteins, and in mammals, birds, and Xenopus, its mRNA was previously detected in extracts of bone, cartilage, and soft tissues (mainly heart and kidney), whereas the protein was found to accumulate mainly in bone. However, at that time, it was not evaluated if this accumulation originated from protein synthesized in cartilage or in bone cells because both coexist in skeletal structures of higher vertebrates and Xenopus. Later reports showed that MGP also accumulated in costal calcified cartilage as well as at sites of heart valves and arterial calcification. Interestingly, MGP was also found to accumulate in vertebra of shark, a cartilaginous fish. However, to date, no information is available on sites of MGP expression or accumulation in teleost fishes, the ancestors of terrestrial vertebrates, who have in their skeleton mineralized structures with both bone and calcified cartilage. To analyze MGP structure and function in bony fish, MGP was acid-extracted from the mineralized matrix of either bone tissue (vertebra) or calcified cartilage (branchial arches) from the bony fish, Argyrosomus regius, ${ }^{1}$ separated from the mineral phase by dialysis, and purified by Sephacryl S-100 chromatography. No MGP was recovered from bone tissue, whereas a protein peak corresponding to the MGP position in this type of gel filtration was obtained from an extract of branchial arches, rich in calcified cartilage. MGP was identified by $\mathrm{N}$-terminal amino acid sequence analysis, and the resulting protein sequence was used to design specific oligonucleotides suitable to amplify the corresponding DNA by a mixture of reverse transcription-polymerase chain reaction (RT-PCR) and $5^{\prime}$ rapid amplification of cDNA (RACE)-PCR. In parallel, ArBGP (bone Gla protein, osteocalcin) was also identified in the same fish, and its complementary DNA cloned by an identical procedure. Tissue distribution/accumulation was analyzed by Northern blot, in situ hybridization, and immunohistochemistry. In mineralized tissues, the MGP gene was predominantly expressed in cartilage from branchial arches, with no expression detected in the different types of bone analyzed, whereas BGP mRNA was located in bone tissue as expected. Accordingly, the MGP protein was found to accumulate, by immunohistochemical analysis, mainly in the extracellular matrix of calcified cartilage. In soft tissues, MGP mRNA was mainly expressed in heart but in situ hybridization, indicated that cells expressing the MGP gene were located in the bulbus arteriosus and aortic wall, rich in smooth muscle and endothelial cells, whereas no expression was detected in the striated muscle myocardial fibers of the ventricle. These results show that in marine teleost fish, as in mammals, the MGP gene is expressed in cartilage, heart, and kidney tissues, but in contrast with results obtained in Xenopus and higher vertebrates, the protein does not accumulate in vertebra of non-osteocytic teleost fish, but only in calcified cartilage. In addition, our results also indicate that the presence of MGP mRNA in heart tissue is due, at least in fish, to the expression of the MGP gene in only two specific cell types, smooth muscle and endothelial cells, whereas no expression was found in the striated muscle fibers of the ventricle.
\end{abstract}

\footnotetext{
${ }^{1}$ The $A$. regius MGP and BGP cDNA sequences were submitted to the GenBank database with accession numbers AF334473 and AF459030, respectively.

The authors have no conflict of interest.
}

\footnotetext{
${ }^{1}$ Department of Biological Sciences, CCMar University of Algarve, Faro, Portugal.

${ }^{2}$ Division of Biology, University of California San Diego, La Jolla, California, USA.
} 
In light of these results and recent information on expression of MGP gene in these same cell types in mammalian aorta, it is likely that the levels of MGP mRNA previously detected in Xenopus, birds, and mammalian heart tissue may be restricted toregions rich in smooth muscle and endothelial cells. Our results also emphasize the need to re-evaluate which cell types are involved in MGP gene expression in other soft tissues and bring further evidence that fish are a valuable model system to study MGP gene expression and regulation. (J Bone Miner Res 2003;18:244-259)

Key words: matrix Gla protein, teleost fish, calcified cartilage, branchial arches, immunohistochemistry, in situ hybridization

\section{INTRODUCTION}

$\mathrm{M}$ ATRIX Gla PROTEIN (MGP) is a secreted vitamin $\mathrm{K}$-dependent protein previously found to accumulate within the organic matrix of mammalian bone from which it was originally purified. ${ }^{(1)}$ MGP was later identified in the organic matrix of bone from several other mammals ${ }^{(2)}$ and amphibians. ${ }^{(3)}$ However, at that time, it was not evaluated whether this accumulation originated from protein synthesized in cartilage or in bone cells because both coexist in skeletal structures of higher vertebrates and Xenopus. MGP was also purified from mammalian calcified cartilage ${ }^{(4)}$ and more recently, the accumulation of the protein was detected at sites of arterial calcification. ${ }^{(5-9)}$ In addition, expression of the MGP gene was found to occur in vitro in different cell lines, ${ }^{(6,10-12)}$ and in vivo in cartilage ${ }^{(13)}$ and in various soft tissues. $^{(3,13,14)}$

Early in vivo experiments using warfarin as a vitamin $\mathrm{K}$ antagonist suggested that MGP could act as a calcification inhibitor. ${ }^{(4,15)}$ This hypothesis was confirmed by mouse genetics because MGP depleted mice display a marked phenotype of abnormal cartilage and artery calcifications, lethal by $6-8$ weeks of age caused by artery rupture. ${ }^{(16)}$ These results, together with several other recent reports, ${ }^{(5,7,17)}$ provided clear evidence that MGP acts in vivo to prevent ectopic calcification. Analysis of in vivo expression of MGP revealed its role in chondrogenesis and its absence from osteoblasts, at least in mouse. ${ }^{(13)}$ The available evidence supports the now widely accepted concept that MGP plays a decisive role as a calcification inhibitor, although its mode of action at the molecular level remains largely unknown.

Fish can be separated into cartilaginous (elasmobranchs) and bony fish (teleosts), and the latter have been classified by some authors as containing either osteocytic or nonosteocytic bone. ${ }^{(18)}$ Teleost fish have a skeleton composed of bone, cartilage, and calcified cartilage, much like higher vertebrates. However, the identification of mammalian-like multinucleated osteoclasts and the occurrence of efficient bone resorption functioning as a calcium homeostasisregulating mechanism is controversial in marine fishes, particularly in those with a non-osteocytic (often also called acellular) bone type. ${ }^{(18-20)}$ In these marine fish, and in contrast with fresh water fish or higher vertebrates, osteoblasts do not usually become trapped as osteocytes in the mineralized matrix of vertebra but recede to the periphery of the bone matrix as mineralization proceeds. Chondrocytes, on the other hand, are usually found within hyaline cartilage that does not mineralize, or are inserted into an Alcian blue stainable extracellular matrix indicative of the presence of cartilage-specific mucopolysaccharides ${ }^{(21)}$ and at the borders of cartilaginous regions undergoing calcification. ${ }^{(19)}$

The identification of MGP in shark vertebra, at levels comparable with those detected in bovine costal calcified cartilage, ${ }^{(22)}$ and the conservation, from cartilaginous fish to mammals, of sites important for protein processing (the Ala-Asn-Ser-Phe or ANSF motif located at positions 19-22 in the shark MGP), ${ }^{(22)}$ for phosphorylation (Glu-Ser-XaaGlu-Ser-Xaa-Glu-Ser-Xaa-Glu ${ }^{(2)}$ or ESXESXESXE motif) and for $\gamma$-carboxylation, ${ }^{(3,22)}$ provide strong evidence for a conserved function over an evolutionary period of more than 400 million years. This finding suggests that teleost fish may be an important link to further understand the function of this protein and emphasizes the need to obtain information on MGP protein structure and gene regulation in this widely diverse group of vertebrates representing the ancestors of all terrestrial vertebrates. In this report we present data on the purification and localization of MGP protein and mRNA in a marine teleost fish (Argyrosomus regius). Our results provide evidence that, in this fish, the MGP protein accumulates primarily in the mineralized extracellular matrix of cartilage and not in bone. Information on specific cell types expressing the MGP gene in teleost heart tissue and arterial wall is also provided.

\section{MATERIALS AND METHODS}

\section{Preparation of mineralized tissues}

Fish vertebra, jaw, and branchial arches were freed from adhering soft tissues, extensively washed in water and acetone, dried, and ground to fine particles in a mortar with liquid nitrogen. The resulting powder was washed three times with a 10-fold excess of $6 \mathrm{M}$ guanidine $\mathrm{HCl}(\mathrm{v} / \mathrm{w})$ to remove the organic matrix, washed extensively, first with water and then with acetone, and air dried.

\section{Identification of Gla-containing proteins in fish tissues}

Protein extraction was performed using a modification of a previously described procedure. ${ }^{(3)}$ In brief, demineralization of bony tissues (vertebra and jaw) and calcified cartilage (branchial arches) was done with a 10-fold excess of $10 \%$ formic acid (v/w) at $4^{\circ} \mathrm{C}$ for $4 \mathrm{~h}$ with continuous stirring. The resulting acid extracts were dialyzed at $4^{\circ} \mathrm{C}$ against $50 \mathrm{mM} \mathrm{HCl}$ using a 3500 molecular weight cut-off tubing (SpectraPor 3; Spectrum, Gardena, CA, USA) with four changes of the medium over 2 days to remove all dissolved mineral. The entire dialyzed extract was freezedried, and two identical samples (approximately $30 \mu \mathrm{g}$ of total protein) from each extract were loaded onto two adjacent lanes and analyzed by SDS-PAGE. After electrophoresis, the two identical lanes were separated by cutting the gel in two, and the protein profile in each half was revealed by 
staining either with Coomassie Brilliant blue or with a Gla-specific color reaction ${ }^{(23)}$ as described below.

Purification of MGP from A. regius calcified cartilage. Crude protein extracts from branchial arches obtained after $50 \mathrm{mM} \mathrm{HCl}$ dialysis (see preparation outlined above) were freeze-dried, dissolved in a minimal amount of $6 \mathrm{M}$ guanidine $\mathrm{HCl}, 0.1 \mathrm{M}$ Tris $\mathrm{pH}$ 9, $10 \mathrm{mM}$ EDTA, and dialyzed against $5 \mathrm{mM}$ ammonium bicarbonate. The resulting precipitate obtained in the branchial arches preparation was dissolved in $2 \mathrm{ml}$ of $6 \mathrm{M}$ guanidine $\mathrm{HCl}, 0.1 \mathrm{M}$ Tris ( $\mathrm{pH}$ 9) and size fractionated over a $2 \times 160 \mathrm{~cm}$ Sephacryl S-100 HR column (Amersham-Pharmacia, Piscataway, NJ, USA) equilibrated with the same buffer. The peak-containing fractions were dialyzed against $50 \mathrm{mM} \mathrm{HCl}$ using SpectraPor 3 tubing (Spectrum) and stored at $-20^{\circ} \mathrm{C}$.

Purification of BGP from A. regius mineralized tissues. Soluble desalted protein extracts obtained after ammonium bicarbonate dialysis as described above were further fractionated by gel filtration over a $2 \times 160 \mathrm{~cm}$ Sephacryl S-100 HR column (Amersham-Pharmacia) equilibrated with 5 $\mathrm{mM}$ ammonium bicarbonate. The fractions containing BGP were identified by SDS-PAGE analysis, pooled, and further purified by ionic exchange in a DEAE-A25 Sephadex (Amersham-Pharmacia). Bound proteins were eluted with a continuous gradient of $0.1 \mathrm{M}$ Tris- $\mathrm{HCl}(\mathrm{pH} 8), 0.1 \mathrm{M}$ Tris- $\mathrm{HCl}$ ( $\mathrm{pH} 8$ ), $\mathrm{NaCl} 0.75 \mathrm{M}$. The resulting peak fractions were desalted by ammonium bicarbonate dialysis as described above and stored at $-20^{\circ} \mathrm{C}$.

\section{$N$-terminal protein sequence analysis}

Intact purified proteins obtained from A. regius were adsorbed onto a polyvinylide nedifluoride (PVDF) membrane using a Prosorb device (Applied Biosystems, Foster City, CA, USA). Samples were then subjected to N-terminal protein sequence analysis using an Applied Biosystems Model 494 sequencer equipped with an on-line highperformance liquid chromatographer (HPLC) for separation and detection of phenylthiohydantoin (PTH) amino acid derivatives.

\section{Detection of the phosphorylated serine residues}

An aliquot of MGP, corresponding to $10 \mu \mathrm{g}$ of protein, was loaded onto four lanes of an $18 \%$ polyacrylamide precast gel containing $0.1 \%$ SDS (NuPage; Invitrogen, La Jolla, CA, USA) run, and transferred to a PVDF membrane (Applied Biosystems). Phosphoserine residues were identified by protein sequence analysis after being converted to S-propylcysteine by reaction with propanetriol, as described elsewhere for ethanethiol. ${ }^{(2,24)}$ The derivatization conditions were the same as for ethanethiol, but the substitution of propanetriol for ethanethiol resulted in PTH-S-propylcysteine, which eluted after PTH-leu on the standard HPLC gradient.

\section{Preparation of MGP and BGP antiserum}

Rabbit antiserum against MGP and BGP from A. regius were obtained at Strategic Biosolutions (Ramona, CA, USA), using in each case the purified protein adsorbed to polyvinylpyrrolidone (PVP-40) as described. ${ }^{(25)}$ The serum collected from the rabbits at regular intervals was tested for immunoreactivity to purified ArMGP and ArBGP in Dotblot and Western blot assays.

\section{Electrophoresis and Western blot}

Total protein $(20-30 \mu \mathrm{g})$ was dissolved in SDS sample buffer containing reducing agent (NuPage, Invitrogen), applied to a $12 \%$ or $4-12 \%$ gradient polyacrylamide precast gel containing $0.1 \%$ SDS (NuPage; Invitrogen) and run at constant $140 \mathrm{~V}$. The gels were stained either with $0.2 \%$ Commassie Brilliant blue R-250 (C.I. 42660; Bio-Rad, Richmond, CA, USA), 10\% trichloroacetic acid, 10\% 5-sulfosalicylic acid, or a DBS-staining solution specific for Gla-containing proteins $(8.5 \mathrm{mM}$ 4-diazobenzene sulfonic acid [DBS]; Sigma, Madrid, Spain; $6.4 \mathrm{mM} \mathrm{NaNO}_{2}$ in $2 \mathrm{M}$ acetate buffer, $\mathrm{pH} 4.6$ ), as described. ${ }^{(23)}$ Blotting onto nitrocellulose (Invitrogen) was performed for $1 \mathrm{~h}$ at $80 \mathrm{~mA}$ using a Bio-Rad Mini Trans-Blot Cell system (Bio-Rad) and a Bis-Tris transfer buffer (NuPage; Invitrogen). The membranes were blocked for $2 \mathrm{~h}$ with $5 \%$ (wt/vol) nonfat dried milk powder in Tris buffer saline Tween (TBST) (15 mM $\mathrm{NaCl}, 10 \mathrm{mM}$ Tris- $\mathrm{HCl}$ buffer, $\mathrm{pH} \mathrm{8,0.05 \%} \mathrm{Tween20;}$ Blotto) and then incubated overnight with ArMGP or ArBGP antiserum diluted 1:100 in Blotto. Immunoreactive protein bands were detected using alkaline phosphataselabeled goat anti-rabbit IgG antibody (Gibco-BRL, Paisley, UK) diluted 1:20,000 in TBST and visualized using NBT/ BCIP substrate solution (Sigma) as described. ${ }^{(26)}$ Negative controls consisted in the substitution of the primary antibody with normal rabbit serum.

\section{Dot-blot analysis}

Polypeptides in the Sephacryl S-100 HR peak fractions including purified ArMGP and ArBGP were deposited in 1 $\mu \mathrm{l}$ aliquots $(0.5 \mu \mathrm{g}$ total protein) onto a nitrocellulose membrane (Invitrogen). Membranes were allowed to dry for $1 \mathrm{~h}$ and blocked for $2 \mathrm{~h}$ with $5 \%$ (wt/vol) dried milk powder in TBST. After incubation overnight at room temperature with ArMGP or ArBGP antiserum diluted 1:100 in Blotto, the immunoreactive protein spots were detected using an alkaline phosphatase-labeled goat anti-rabbit $\operatorname{IgG}$ antibody (Gibco-BRL) diluted 1:20,000 in TBST and visualized using 5-bromo 4-chloro 3-indolylphosphate/nitro blue Tetrazolium (NBT/BCIP) substrate solution (Sigma) as described. ${ }^{(26)}$ Negative controls consisted in the substitution of the primary antibody with normal rabbit serum.

\section{Cloning of a partial ArMGP cDNA}

The N-terminal amino acid sequence of the ArMGP mature protein (29 residues) obtained by protein sequence analysis was used to construct two forward oligonucleotide primers (ArMGP1F and 2F) spanning, respectively, from residues 8 to $16 \quad\left[5^{\prime}\right.$-ga(ag)ag(ct)gc(agct)ga(ag)ga(ct)ct(agct)tt(ct)gt(agct)cc- $\left.3^{\prime}\right]$ and from residues 20 to 27 [5'gc(agct)aa(ct)(at)(gc)(agct)tt(ct)atgac (agct)cc(agct)ca- $\left.3^{\prime}\right]$. Total RNA was isolated from kidney following an established method (RNAWIZ; Ambion, Austin, TX, USA) and reverse transcription of the mRNA was performed at $42^{\circ} \mathrm{C}$ for60minusing anoligo-d(T)-adapter [ $5^{\prime}$-acgcgtcgacctcgaga$\left.\operatorname{tcgatg}(\mathrm{t})_{18^{-}} 3^{\prime}\right]$ and the Moloney murine leukemia virus re- 
Table 1. N-Terminal Amino Acid Sequence Analysis of Peak Fractions Obtained From Sephacryl S-100 HR Purification (Fig. 1) of Acid Extract From A. regius Branchial Arches Calcified Cartilage

\begin{tabular}{|c|c|}
\hline Fraction & $\mathrm{N}$-Terminal amino acid sequence ${ }^{(b)}$ \\
\hline & 20 \\
\hline 64 & $Y$ E S H E S X E S A E D L F V P X Q X A N S F M T P X R G \\
\hline 72 & 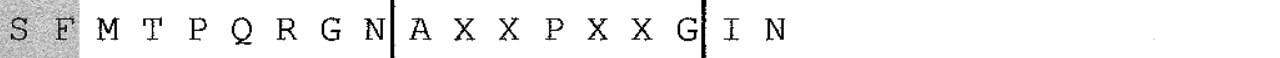 \\
\hline 76 & A Y S P G R G \\
\hline 88 & A $A K E L T L A Q T E S L R E V C E T N M A C D E M A D A$ \\
\hline
\end{tabular}

Peak fractions were collected and dialyzed against $50 \mathrm{mM} \mathrm{HCl}$. Ten microgram aliquots were lyophilized, and analyzed by SDS-PAGE (Fig. 1BI). On identification of a single protein band, intact proteins and fragments were transferred onto a Prosorb device and its N-terminal sequence determined as described in the Material and Methods section.

(a) Fraction number corresponds to the elution profile shown in Fig. 1.

(b) The $\mathrm{N}$-terminal sequence presented in this table is numbered from the first amino acid residue obtained from sequence determination. X, non-identified amino acid residue. The sequence of peak 72 corresponding to N-terminal sequence of peak 76 is boxed. The conserved ANSF sequence site is boxed and shown in gray. The glycine residue (in bold) in fraction 76 was found to be a proline in the cDNA sequence (Fig. 3, residue 35 of mature ArMGP protein).

verse transcriptase (M-MLV-RT; Promega, Madison, WI, USA). A partial $A$. regius cDNA was amplified by the polymerase chain reaction (PCR) using a nested PCR with ArMGP1F and $2 \mathrm{~F}$ and a reverse primer corresponding to the adapter sequence $\left(5^{\prime}\right.$-acgcgtcgacctcgagatcgatg- $\left.3^{\prime}\right)$. PCR reactions were conducted first with ArMGP1F for 30 cycles (1 cycle: $45 \mathrm{~s}$ at $95^{\circ} \mathrm{C}, 60 \mathrm{~s}$ at $55^{\circ} \mathrm{C}$, and $60 \mathrm{~s}$ at $72^{\circ} \mathrm{C}$ ) and then with ArMGP2F for 30 cycles ( 1 cycle: $45 \mathrm{~s}$ at $95^{\circ} \mathrm{C}, 60 \mathrm{~s}$ at $52^{\circ} \mathrm{C}$, and $60 \mathrm{~s}$ at $72^{\circ} \mathrm{C}$ ) followed in each case by a 10 minute final extension at $72^{\circ} \mathrm{C}$ with AmpliTaq DNA polymerase (Perkin Elmer, Boston, MA, USA). The results were visualized on a $2 \%$ agarose gel and the fragment corresponding to the putative MGP cDNA was cut from the gel, eluted (Concert Rapid Gel Extraction System Kit; GibcoBRL), and cloned into the vector pGEM-T-easy (Promega). Final identification was achieved by sequence analysis using the ${ }^{\mathrm{T} 7}$ Sequencing Kit (USB; Amersham-Pharmacia).

\section{Cloning of the $5^{\prime}$ end of ArMGP cDNA}

A DNA fragment containing the $5^{\prime}$ end of the ArMGP cDNA was obtained by $5^{\prime}$ rapid amplification of cDNA (RACE)-PCR using the Marathon cDNA Amplification Kit (Clontech, Palo Alto, CA, USA) and poly $\left(\mathrm{A}^{+}\right)$RNA as template. Poly $\left(\mathrm{A}^{+}\right)$RNA was purified from a mix of $A$. regius tissues (heart, kidney, and vertebra) with the QuickPrep Micro mRNA Purification Kit (AmershamPharmacia). Amplification was performed with Advantage Klen Taq polymerase (Promega) using a forward primer (AP1; Clontech) specific for the 5'-anchor and an ArMGPspecific reverse primer (ArMGP1R; 5'-cgctggagacttcaccgtcctcatc- $3^{\prime}$ ) designed according to the partial ArMGP cDNA sequence previously obtained. Amplification conditions were those suggested by the manufacturer. The resulting PCR products were fractionated by agarose gel electrophoresis, purified from the gel using the Concert Rapid Gel
Extraction System Kit (Gibco-BRL), and cloned into the vector pGEM-T-easy (Promega). Final identification of the cloned DNA fragments was achieved by sequence analysis as described above.

\section{Cloning of a partial ArBGP cDNA}

Total RNA was isolated from vertebra using the RNAWIZ method (Ambion), and reverse transcription of the mRNA was achieved as described for ArMGP cDNA. A partial A. regius cDNA was amplified by PCR using a forward oligonucleotide primer spanning residues 14-20 (ArBGP3F, 5' -(ac)g(agct)ga(ag)gt(agct)tg(ct)ga(ag)ac(agct)aa(ct)-3') of the N-terminal amino acid sequence of ArBGP (Table 1, fraction 88) previously obtained and a primer corresponding to the adapter sequence (5'-acgcgtcgacctcgagatcgatg- $\left.3^{\prime}\right)$. PCR reaction conditions were identical to those previously described for amplification with ArMGP1F. The PCR products were visualized on a $2 \%$ agarose gel, and the fragment corresponding to the putative partial ArBGP cDNA was excised from the gel, eluted (Concert Rapid Gel Extraction System; Gibco-BRL), and cloned into pGEM-T-easy (Promega). DNA sequence analysis was performed as described above.

\section{Cloning of the $5^{\prime}$ end of ArBGP $c D N A$}

The 5' end of the ArBGP cDNA was obtained by 5'RACE-PCR as described for ArMGP cDNA with a 5'anchor-specific forward primer (AP1; Clontech) and a ArBGP-specific reverse primer (ArBGP1R; 5'-gtgtcacacgctggcacacatttggaa- $\left.3^{\prime}\right)$. Poly $\left(\mathrm{A}^{+}\right)$RNA purified from a mix of $A$. regius tissues (heart, kidney, and vertebra) was used as template. The resulting PCR products were purified, cloned into pGEM-T-easy (Promega), and identified by DNA sequence analysis as described above. 


\section{Northern blot analysis}

Total RNA from several A. regius tissues (vertebra, branchial arches, heart including bulbus arteriosus, ventricle and a fragment of aorta, liver, kidney containing internal blood vessels, intestine, and pancreas) was prepared following an established method (RNAWIZ; Ambion). The RNA obtained was then fractionated on a $1.4 \%$ formaldehydecontaining agarose gel and transferred onto a $0.45-\mu \mathrm{m} \mathrm{N}^{+}$ Nylon membrane (Nytran; Schleicher \& Schuell, Dassel, Germany) by a capillary method. ${ }^{(26)}$ Pre-hybridization was carried out with a commercially available hybridization buffer at $42^{\circ} \mathrm{C}$ (Ultrahyb; Ambion) for $2 \mathrm{~h}$. The partial ArMGP cDNA previously obtained was labeled with $\left[\alpha-{ }^{32} \mathrm{P}\right] \mathrm{dCTP}$, using the T7QuickPrime Kit (AmershamPharmacia) and separated from unincorporated nucleotides on a Microspin S-200HR column (Amersham-Pharmacia). Hybridization was performed overnight under the same conditions described for pre-hybridization after adding the probe. Blots were washed twice in $2 \times \mathrm{SSC}(1 \times \mathrm{SSC}: 0.15$ $\mathrm{M} \mathrm{NaCl}, 0.015 \mathrm{M}$ sodium citrate [pH 7]), $0.1 \% \mathrm{SDS}$ at $42^{\circ} \mathrm{C}$ for 5 minutes, twice in $0.1 \times \mathrm{SSC}, 0.1 \% \mathrm{SDS}$ at $42^{\circ} \mathrm{C}$ for 15 minutes, and once with $0.1 \times \mathrm{SSC}, 0.1 \% \mathrm{SDS}$ at $50^{\circ} \mathrm{C}$ for 30 minutes. Positive hybridization signals were detected by autoradiography using a GS-505 Molecular Imager System (Bio-Rad). After autoradiography, the probe was boiled off by washing the membrane three times for 15 minutes with boiling $0.1 \%$ SDS solution before the second hybridization with a specific ArBGP cDNA probe labeled with $\left[\alpha-{ }^{32} \mathrm{P}\right]$ $\mathrm{dCTP}$ as described for ArMGP. Prehybridization, hybridization, and washing conditions were as described above for hybridization with ArMGP cDNA probe. Autoradiography was also performed as described above. Relative density of BGP/MGP hybridization signals versus the $18 \mathrm{~S}$ ribosomal RNA in the same sample were determined using the Gel Doc (Bio-Rad) equipped with Quantity One version 4.2.1 software (Bio-Rad).

\section{In vitro calcification assay}

Different concentrations of $A$. regius MGP $(0-20 \mu \mathrm{g} / \mathrm{ml})$ and $10 \mu \mathrm{g} / \mathrm{ml}$ of bovine MGP were added to $2 \mathrm{ml}$ aliquots of human heparinized plasma containing $2 \mathrm{mg}$ of basetreated human aortic media elastin, 800,000 CPM of ${ }^{45} \mathrm{Ca}$ (NEN/Perkin Elmer/Life Sciences, Boston, MA, USA), and $0.02 \% \mathrm{NaN}_{3}$, and incubated at $37^{\circ} \mathrm{C}$ for 8 days. ${ }^{(27)}$ After 8 days, the elastin samples were removed from plasma, washed with $1 \mathrm{ml}$ of $20 \mathrm{mM}$ HEPES (pH 7.4) and $0.15 \mathrm{M}$ $\mathrm{NaCl}$, and demineralized with $1 \mathrm{ml}$ of $150 \mathrm{mM} \mathrm{HCl}$ for $24 \mathrm{~h}$ at $37^{\circ} \mathrm{C}$. The amount of ${ }^{45} \mathrm{Ca}$ incorporation was determined by measuring the radioactivity in $100 \mu \mathrm{l}$ of the elastin acid extracts.

\section{Histological sample preparation}

Tissues of $A$. regius (branchial arches, vertebra, jaw) and S. aurata (blood vessel, heart including bulbus arteriosus, ventricle, and aorta) were handled under sterile conditions to avoid degradation of RNA in the sample. The samples were immediately fixed by immersion in $4 \%$ freshly prepared sterile paraformaldehyde in $0.1 \mathrm{M}$ sodium phosphate buffer, $\mathrm{pH} 7.2$, overnight at $4^{\circ} \mathrm{C}$. Bone and calcified carti- lage samples were decalcified for 4 days in sterile buffered EDTA (0.3 M EDTA, 0.15 M NaCl, 0.1 M Tris-HCl, pH 7.6), washed $3 \times 10$ minutes with $0.1 \mathrm{M}$ sodium phosphate buffer, pH 7.2, dehydrated with increasing methanol concentrations, and defatted with xylene before embedding in paraffin. Longitudinal sections 6- to $8-\mu \mathrm{m}$ thick were mounted on slides coated with 3-(triethoxysilyl)propylamine (Merck, Darmstadt, Germany). Routine staining methods using Harris hematoxylin (CI 75290; Sigma) and Alcian blue 8GX (CI 74240; Sigma) were carried out in adjacent sections.

\section{Immunohistochemistry}

Immunohistochemical staining experiments on tissue sections were done using a secondary antibody peroxidaseconjugated goat anti-rabbit IgG. After deparaffination, the endogenous peroxidase activity was blocked with $3 \% \mathrm{H}_{2} \mathrm{O}_{2}$ in Coons buffer (CBT: 0.1 M Veronal, $0.15 \mathrm{M} \mathrm{NaCl}, 0.1 \%$ Triton X-100) for 15 minutes. Nonspecific binding to sections was blocked with $0.5 \%$ (wt/vol) bovine serum albumin (BSA) in CBT for 30 minutes. Incubation with specific primary polyclonal antibody (ArBGP antiserum diluted 1:500 and ArMGP antiserum diluted 1:250 in CBT) was performed overnight in a humidified chamber at room temperature. After several washes in CBT, sections were incubated in the same buffer for $1 \mathrm{~h}$ at room temperature with peroxidase-labeled goat anti-rabbit IgG (Gibco-BRL) secondary antibody at a 1:1500 dilution. Peroxidase activity was revealed using $0.025 \%$ 3,3'-diaminobenzidine (Sigma) as described. ${ }^{(28)}$ Negative controls consisted in the substitution of the primary antibody with normal rabbit serum. After thorough washing, some sections were directly mounted, and others were counterstained with Alcian blue and hematoxylin as described, ${ }^{(29)}$ washed in running water, dehydrated, cleared, and mounted in Aquatex (Merck). Results were visualized with a BX41 Olympus light microscope linked to a C3030 Olympus digital camera (Olympus, Barcelona, Spain).

\section{Synthesis of riboprobes for in situ hybridization}

Probes were labeled with digoxigenin using a RNA labeling kit (Roche, Mannheim, Germany) according to the manufacturer's instructions. A 708-bp fragment of ArMGP cDNA (spanning from nucleotide 197 to the $3^{\prime}$ end of the ArMGP cDNA) and a SpMGP cDNA (accession number AY065652) cloned in pGEM-T-easy (Promega) were linearized with $A p a \mathrm{I}$ and transcribed with SP6 RNA polymerase to generate an antisense riboprobe or linearized with SacI and transcribed with T7 RNA polymerase to generate a sense riboprobe. Specificity of these probes was confirmed by Northern blot analysis.

\section{In situ hybridization analysis}

Treatment of slides and hybridization conditions were as previously described. ${ }^{(30)}$ Hybridization was performed at $55^{\circ} \mathrm{C}$ overnight in a humidified chamber. After hybridization, the sections were washed three times in $2 \times \mathrm{SSC}$ at $55^{\circ} \mathrm{C}$ for 30 minutes and treated with $10 \mu \mathrm{g} / \mathrm{ml}$ of RNase A in $10 \mathrm{mM}$ Tris- $\mathrm{HCl}$, pH 7.6, $1 \mathrm{mM}$ EDTA, and $0.5 \mathrm{M} \mathrm{NaCl}$ 
at $37^{\circ} \mathrm{C}$ for 30 minutes. Sections were washed twice at $55^{\circ} \mathrm{C}$ with $1.4 \times$ SSC, $0.6 \%$ CHAPS (3-[(3-cholamidopropyl)dimethylammonio]1-propanesulfonate; Sigma), and once with 1:1 PTW: (0.1 M maleic acid, $0.15 \mathrm{M} \mathrm{NaCl}, \mathrm{pH} 7.5)$, (PTW: $137 \mathrm{mM} \mathrm{NaCl}, 2.7 \mathrm{mM} \mathrm{KCl}, 1.8 \mathrm{mM} \mathrm{KH} \mathrm{PO}_{4}, 10$ $\mathrm{mM} \mathrm{Na} \mathrm{HPO}_{4}, 0.1 \%$ Tween-20) for 10 minutes at room temperature. Detection of hybridized probe was done with the alkaline phosphatase-coupled antidigoxigenin-AP antibody (Boehringer, Mannheim, Germany) and NBT/BCIP substrate solution (Sigma) as described. ${ }^{(30)}$ The controls included hybridization with the sense probes, RNase treatment before hybridization, and use of neither the antisense RNA probe nor anti-digoxigenin antibody. All three experiments showed no detectable signals.

\section{RESULTS}

\section{Identification of sites of MGP accumulation in fish}

Based on results previously obtained in mammals, ${ }^{(2)}$ shark, ${ }^{(22)}$ and Xenopus, ${ }^{(3)}$ it was hypothesized that bony fish vertebra would be a good source of MGP. However, attempts to purify MGP from vertebra of different marine teleost fishes (Sparus aurata; Halobatrachus didactylus; Xiphias gladius) were always unsuccessful. We then searched different mineralized tissues (vertebra, jaw, branchial arches) collected from various bony fishes (Argyrosomus regius, Sparus aurata, Polyprion americanus, Halobatrachus didactylus) and from blue shark (Prionace glauca, used as positive control) for the presence of Glacontaining proteins using the Gla-specific DBS staining method. ${ }^{(23)}$ Their migration profile in SDS-PAGE was then compared with those of BGP (previously purified from a teleost fish) ${ }^{(31)}$ and MGP (purified from blue shark as described) ${ }^{(22)}$ (results not shown). Only protein extracts from the calcified cartilage of branchial arches showed a significant positive signal with DBS staining method comparable in size with shark MGP (results not shown). A. regius, a marine fish captured in the wild off the southern Portuguese coast, was chosen as a donor fish to perform the large scale purification of MGP because of its large size (up to $60 \mathrm{lbs}$ ) and resulting ease in obtaining large amounts of calcified branchial arches.

\section{Large scale purification and identification of ArMGP by amino acid sequence analysis}

MGP was purified from the acid extract of A. regius branchial arches by gel filtration over a Sephacryl S-100 HR column as described in the Material and Methods section. The chromatogram, shown in Fig. 1, revealed a peak eluting at fractions $62-65$, corresponding to the elution volume for MGP in this type of column (approximately $250 \mathrm{ml}$ ). Only one protein with an apparent molecular weight of $20 \mathrm{kDa}$ was identified after SDS-PAGE in the peak fraction (Fig. 1BI, fraction 64). N-terminal protein sequence analysis confirmed its identity to be ArMGP (Table 1) based on the fact that the first 29 amino acid residues sequenced showed high homology with previously sequenced MGPs. The peak fractions corresponding to the next four small peaks (i.e., peaks corresponding to fractions $72,76,81$, and 88 ; Fig. 1A) were also collected, and after dialysis against $50 \mathrm{mM} \mathrm{HCl}$, the
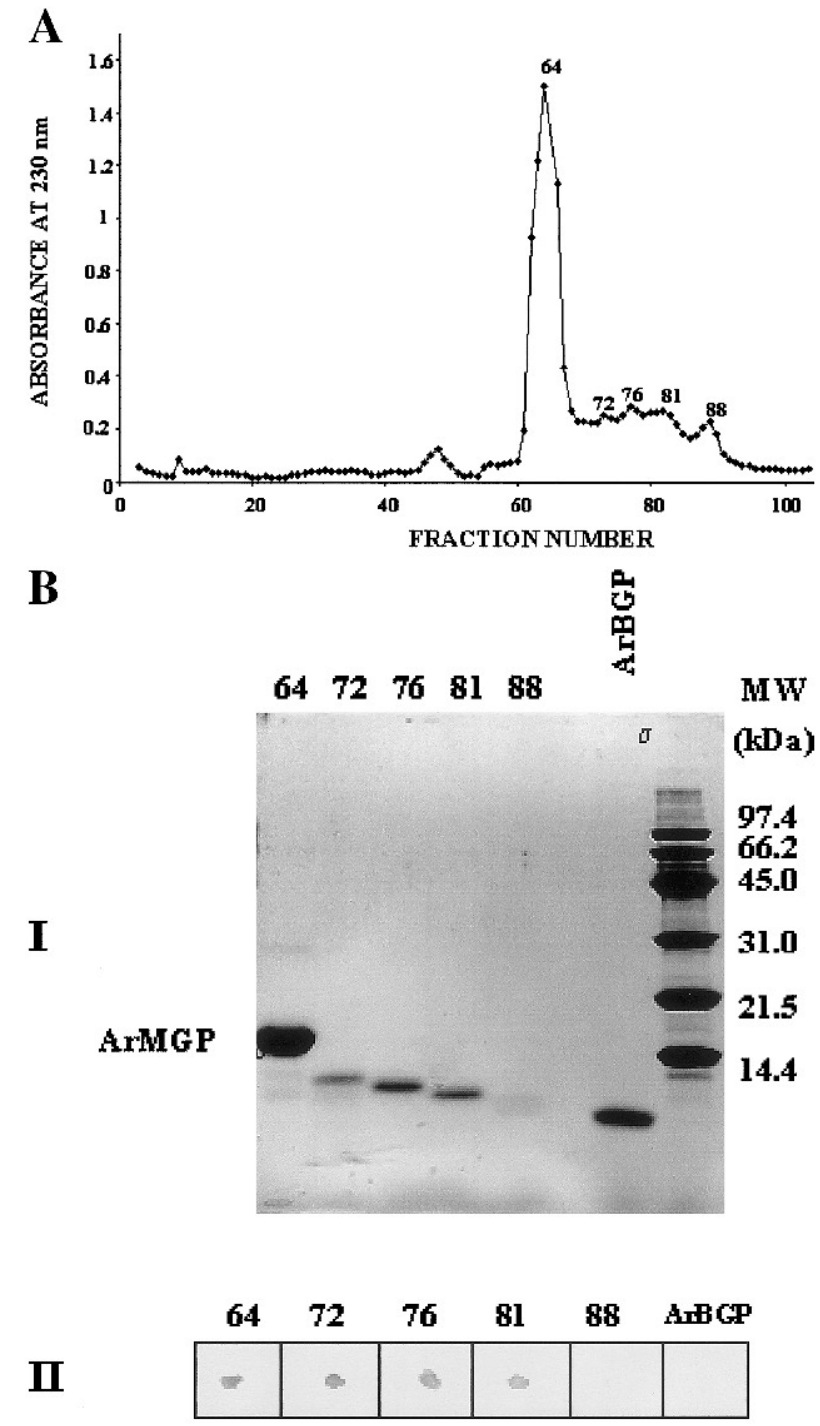

FIG. 1. Purification of A. regius MGP from branchial arches. (A) Sephacryl S-100 HR elution profile of A. regius MGP extracted from branchial arches. Fractions of approximately $4.2 \mathrm{ml}$ were collected every 30 minutes. Protein purification profile was obtained by measuring absorbance of effluent fractions at $230 \mathrm{~nm}$. Peak fractions were collected and dialyzed against $50 \mathrm{mM} \mathrm{HCl}$, lyophilized and resuspended in SDS-sample buffer (Novex; Invitrogen). (BI) Migration of peak fractions $64,72,76,81$, and 88 on a $18 \%$ SDS-PAGE (Novex; Invitrogen) stained with Coomassie Brilliant blue. (BII) Immunoreaction of the pooled fractions on treatment with 1:100 dilution of ArMGP antiserum as primary antibody, obtained by Dot-blot analysis, as described in the Materials and Methods section.

resulting purified protein fractions were analyzed by SDSPAGE (Fig. 1BI). Because each of them appeared to migrate under these SDS-PAGE conditions as a single protein band, their $\mathrm{N}$-terminal protein sequence was also determined, and the sequences obtained are shown in Table 1. Fraction 72 corresponded to the ArMGP fragment generated by proteolysis at the Ala-Asn-Ser-Phe (ANSF) site (residues 20-23 in sequence obtained from fraction 64). From fraction 76 we obtained a weak signal, which was not possible to identify after the first seven amino acid residues and 


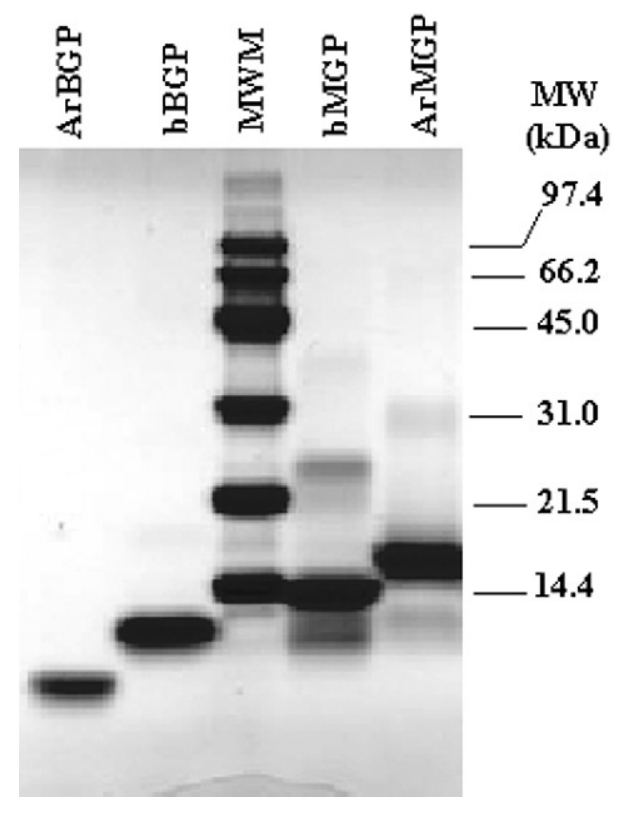

FIG. 2. Comparison of the migration profile of A. regius MGP and BGP and their bovine counterparts on an $18 \%$ SDS-PAGE gel (Novex; Invitrogen). Each lane was loaded with $10 \mu \mathrm{g}$ of protein and the gel was stained with Coomassie Brilliant blue as described in the Materials and Methods section. ArBGP, A. regius BGP; ArMGP, A. regius MGP; bBGP, bovine BGP; bMGP, bovine MGP; MWM, low range molecular weight markers from BioRad.

corresponded to Ala-Tyr-Ser-Pro-Gly-Arg-Gly (AYSPGRG). This sequence shared some homology with residues 10-16 identified in fraction 72 at the region AXXPXXG (Table 1). Fraction 81 contained a mixture of fragments, and it was not possible to obtain an unambiguous protein sequence. Fraction 88 corresponded to a peptide with a $\mathrm{N}$-terminal sequence highly homologous to those of other mature fish BGPs previously purified $^{(31,32)}$ and was therefore tentatively identified as ArBGP. Comparison of the migration profile of ArMGP with that of comparable with amounts of bovine MGP indicated that ArMGP migrated as a larger entity (around $20 \mathrm{kDa}$ ) than bovine MGP (around $14 \mathrm{kDa}$ ) over an 18\% SDS-PAGE (Fig. 2 ). On the contrary, ArBGP migrated as a smaller entity than the bovine BGP under the same electrophoresis conditions (Fig. 2).

\section{Identification of phosphoserine residues in ArMGP}

To verify the level of phosphorylation of serines contained within its first 10 amino acid residues, ArMGP was treated with propanethiol to convert the putative phosphoserine residues to S-propylcysteine ${ }^{(24)}$ and then subjected to N-terminal sequence analysis. The HPLC separation of the PTH-amino acid derivative for residues 3, 6, and 9 revealed, in each case, a single peak coeluting with PTH-Spropylcysteine, but a PTH-serine was also present. These results confirmed that ArMGP was partially phosphorylated. An additional phosphorylated serine was identified at residue 7, making ArMGP the only MGP protein so far identified with four sites of phosphorylation at its N-terminal moiety.

\section{Molecular cloning of ArMGP cDNA}

The ArMGP cDNA (Fig. 3) was obtained from kidney RNA by a combination of RT-PCR and 5'-RACE-PCR amplification, as described in the Material and Methods section. The predicted amino acid sequence indicated the presence of a signal peptide of 19 amino acid residues and was in full agreement with the $\mathrm{N}$-terminal protein sequence obtained for the mature ArMGP (fraction 64, Table 1). However, cDNA sequence indicated that residue 35 of the mature protein was a proline, and not a glycine, as indicated from direct amino acid sequence of peak 76 (Table 1). The longest ArMGP cDNA obtained spans 904 bp and comprises an open reading frame of $357 \mathrm{bp}$ encoding a polypeptide of 118 amino acid residues and 5' and 3' UTRs of 118 and $429 \mathrm{bp}$, respectively. The site of insertion of the polyA tail is located $23 \mathrm{bp}$ after a consensus polyadenylation signal (aataaa; Fig. 3).

\section{Molecular cloning of ArBGP cDNA}

The ArBGP cDNA (Fig. 4) was cloned from vertebra RNA by a combination of RT-PCR and 5'-RACE-PCR amplification, as described in the Material and Methods section. The deduced amino acid sequence was in full agreement with the protein sequence obtained by $\mathrm{N}$-terminal sequence analysis of the purified mature ArBGP (fraction 88, Table 1). The ArBGP cDNA spans 594 bp and comprises an open reading frame of 294 bp, encoding a polypeptide of 97 amino acid residues, and 5' and 3'UTRs of 80 and $220 \mathrm{bp}$, respectively. The site of insertion of the polyA tail is located 5 bp after the second of two consecutive consensus polyadenylation signals (aataaa; Fig. 4).

\section{Tissue distribution of MGP and BGP $m R N A$}

The presence of MGP mRNA in A. regius was determined by Northern blot analysis in tissues obtained at dissection of the animal, as described in the Material and Methods section. From all tissues analyzed, heart extract presented the strongest signal (5-fold higher than kidney, Figs. 5B and 5D), but ArMGP mRNA was also seen in calcified cartilage (branchial arches), vertebra, and kidney extracts (Figs. 5B and 5D). The same blot was washed free from ArMGP cDNA probe and hybridized with labeled ArBGP cDNA as described in the Material and Methods section. As expected, a strong positive signal was detected for BGP mRNA in vertebra-derived RNA, but a weaker signal was also detected in RNA from branchial arches (Figs. 5C and 5D). Comparable results were obtained in an independent experiment using tissues from a different specimen (results not shown).

\section{Western blot analysis of $\gamma$-carboxylated ArMGP and ArBGP}

Both MGP and BGP proteins purified from A. regius tissues stained positive with the Gla-specific method (DBS), indicating that both were $\gamma$-carboxylated (results not shown). Specificity of rabbit polyclonal antibodies in antiserum developed against purified BGP and MGP (see Ma- 


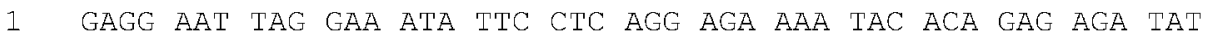

47 TTC CAA GAC TTC TAA CTC CAC AAT CAT CTT CCA AGC AGA CAG GCA $-19$ GAT AAA CCA GAA CCC CCC CCC ACA AGG ATG AGG AGC CTT CTT CAG

$-13$ Met Arg Ser Leu Leu Gln $+1$

137 TTT CTG GCA CTC AGT GCT GCG ATC GCT CTC TGT GTC TGC TAT GAG Phe Leu Ala Leu Ser Ala Ala Ile Ala Leu Cys Val Cys Tyr Glu $+5$ ArMGP1F $+\mathbf{1 1 4}$

182 TCT CAT GAA AGC TCA GAA TCT GCA GAA GAT CTG TTT GTG CCT CCA Ser His Glu Ser Ser Glu Ser Ala Glu Asp Leu Phe val pro Pro $+20$ ArMGP2F $+29$

227 CAA CAA GCC AAC TCG TTC ATG ACG CCA CAG AGG GGC AAC GCA TAC Gln Gln Ala Asn Ser Phe Met Thr Pro Gln Arg Gly Asn Ala Tyr $+35$ $+44 \quad$ ArMGP1R

272 AGC CCA CCC AGG GGG AAC GGC AAC AAC TTC AAC TTG ATG AGG ACG Ser Pro Pro Arg Gly Asn Gly Asn Asn Phe Asn Leu Met Arg Thr $+50$ $+59$

317 GTG AAG TCT CCA GCG GAG AGG CGT GCA GAG ACC TGC GAG GAC TAT Val Lys Ser Pro Ala Glu Ara Ara Ala Glu Thr Cys Glu Asp Tyr $+65$ $+74$

362 TCT CCA TGC CGC TTC TAC GCC TAC CGC CAC GGC TTC CAG CAG GCC Ser Pro Cys Arg Phe Tyr Ala Tyr Arg His Gly Phe Gln Gln Ala $+80$ $+89$

407 TAC CAG AGA TAC TTC GGC TCC GGG ACT CAT CCC CAG CAG AGA CCA Tyr Gln Arg Tyr Phe Gly Ser Gly Thr His Pro Gln Gln Arg Pro $+95$ $+99$

452 GCA GCC GCG GCT CGC CGA TAC TAA ACT AAG AGT ATC TTA TCT GTC Ala Ala Ala Ala Arg Arg Tyr ***

497 ACA GGG TTT GCA GAA TTA TCT CAT TAT CGT CTG GAA ATG AGC GCG

542 CCG TGC CTC CAT TCC ACA TAA CTT TTT ATA TAA TTT ATG TAG CTG

587 TTT TTG TGG CCT CTT CTG GAG ACA CAT TTT ATA AAC ACA GAG GCC

632 TCC AGC GTG GCT CAG CTG TTA CAG TAA CCC CAT CAT tAT ACA CAT

677 GTA GAA AAT CAC GGC CCA TCT CTC GTG TAA TCT CAG GAT AAC TTT

722 TAT CCA CTA TTA TCA CAC CTC CCC GGC ATT TAT GAG CTT TGT GTG

767 ACG TGC TTT TAT TAA ATG TTT CGG TCA CCA TCC ACT TTC TTA CAT

812 TAT CCA TGT GTG TAT CCA GCC CAG CGC TGC TGT CAC TGA TTG TTT

857 CCA TTG CTT TGA TTT GAA AAA TAA AAT TCA CTT TAT TGG GTT TTG

902 TСТ
FIG. 3. Nucleotide sequence of the cDNA encoding A. regius MGP. The cDNA was obtained by a combination of RT-PCR and 5'RACE-PCR amplification. Numbering on the side is according to the first nucleotide (identified as 1) from the longest $5^{\prime}$ RACE extension product obtained. Amino acid residues are numbered according to residue 1 of the mature protein (identified as the first amino acid residue obtained on $\mathrm{N}$-terminal protein sequence analysis) and are shown above the respective DNA sequence. The stop codon is indicated in bold and marked by asterisks, and the polyadenylation signal is underlined and bold. Sequences used for the construction of ArMGP1F, ArMGP2F, and ArMGP1R oligonucleotides are denoted by horizontal arrows. terial and Methods section for details) was confirmed by Western blot analysis. The ArBGP antibodies did not recognize ArMGP, whereas anti-ArMGP antibodies only recognized fish MGP and not fish BGP (Fig. 6). ArMGP polyclonal antibodies were also able to detect purified peptide fragments derived from mature ArMGP (Fig. 1BII, Dot-blot of peak fractions 72, 76, and 81) and obtained after size separation of branchial arches acid extract over Sephacryl S-100 HR (Fig. 1). Small amounts of ArMGP peptides were also detected in peak fraction 88, which essentially contained ArBGP (Fig. 1B and Table 1).
Identification of sites of MGP and BGP accumulation in mineralized tissues using the specific polyclonal antibodies developed

In teleost fish, calcified tissues include cartilage and bone and are located in gills, jaw, and vertebra. Gills in A. regius, like in many other teleost fish species, are composed of four to five branchial arches on each side of the esophagus. Two sets of primary lamellae are attached to each branchial arch (Fig. 7A). Both branchial arches and primary lamella (also called branchial filament) have a central core of cartilage. 


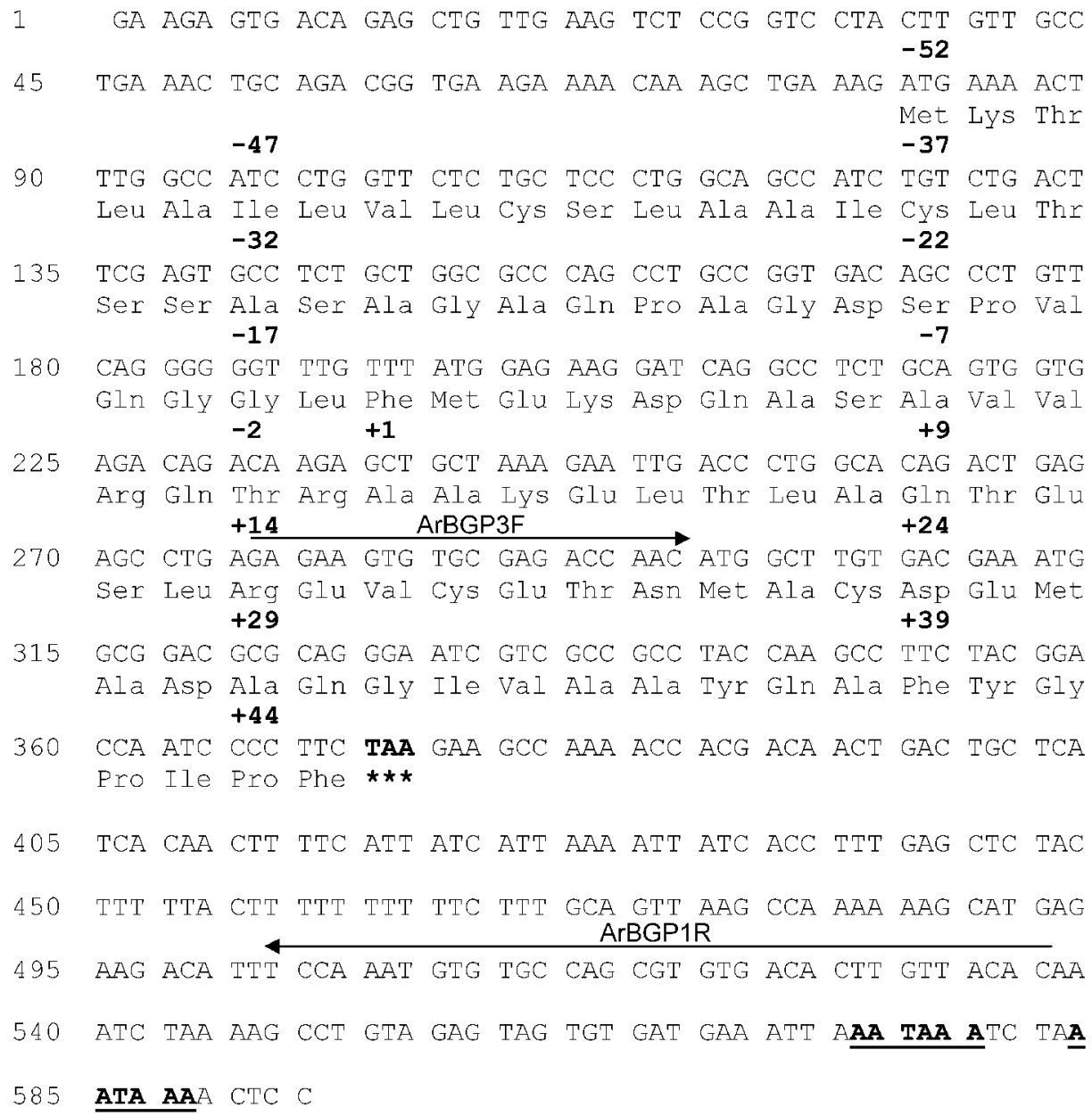

The cartilage in branchial filaments presents proliferating chondrocytes, whereas the branchial arches contain mature chondrocytes immersed in a homogeneously staining (hyaline) cartilage matrix (Figs. 7A and 7B). In A. regius gills, MGP was localized using the specific ArMGP polyclonal antibodies developed (see Materials and Methods section) and found to accumulate mainly within proliferating chondrocytes and pericellular cartilage matrix in the incipient calcified cartilage of branchial arches and filaments, in regions that counterstained positive with Alcian blue (which specifically identifies the acid mucopolysaccharides of cartilage; Figs. 7C and 7D). Hyaline cartilage from branchial arches showed no ArMGP immunostaining (results not shown), indicating that MGP did not accumulate in this matrix. BGP immunoreactivity was detected solely outside the chondrocyte-containing zone, within branchial primary filaments (Figs. 7E and 7F). This immunoreactivity was in the cytoplasm of some cells in the basal zone of branchial filaments near the branchial arches (Fig. 7E) and within the extracellular matrix in the medial zone, a region free from chondrocytes or Alcian-blue stained cartilage extracellular matrix (Fig. 7F). BGP was also accumulated in the mineralized bone matrix of vertebra (Fig. 7G). No MGP was found to accumulate within this mineralized bone matrix in vertebra and jaw, but some was detected in the cartilaginous layer from the neural arch immediately adjacent to the BGP-containing mineralized vertebra bone matrix (Fig. $7 \mathrm{H})$. No MGP/BGP staining was seen when rabbit preimmune serum was used instead of the specific ArMGP/ ArBGP antibodies (results not shown).

\section{Identification of MGP gene expression in cells within calcified tissues and vascular system}

In situ hybridization techniques were performed in vascular structures (ventral aorta, ventricle, and bulbus arteriosus) to provide a better understanding of the results obtained by Northern analysis in extracts of heart samples. Because of the difficulty for obtaining hearts from wild $A$. regius specimens, hearts from the teleost fish Sparus aurata, a species routinely produced in aquaculture in Southern Portugal and also included in the type of fishes with acellular bone, was used. In S. aurata, like in A. regius and in many other teleost fish species, the heart is composed of four chambers: sinus venosus, atrium, ventricle, and bulbus arteriosus. ${ }^{(33)}$ The bulbus arteriosus lacks cardiac muscles and has a white elastic structure mainly composed of elastic fibers and smooth muscle cells, covered on the inner side with endothelial cells (endocardium) (Fig. 8A). The ventricle, like the rest of cardiac cavities, is composed mainly of 
A

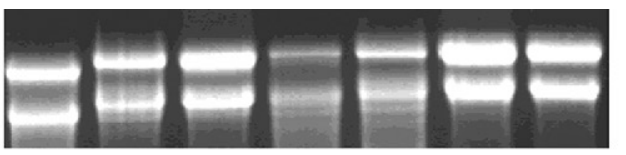

$428 \mathrm{~S}$

$118 \mathrm{~S}$

B

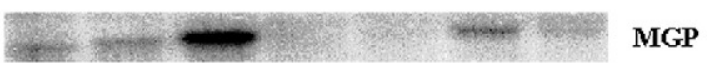

$\mathrm{C}$

BGP

D

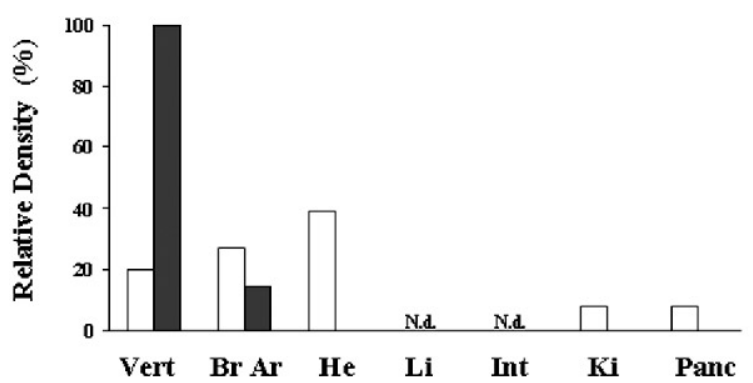

FIG. 5. Tissue distribution of ArMGP and ArBGP in A. regius tissues by Northern blot analysis. Total RNA extracted from several A. regius tissues (vertebra, Vert; branchial arches, Br Ar; liver, Li; heart, He; intestine, Int; kidney, Ki; Pancreas, Panc) was fractionated on a $1.4 \%$ formaldehyde-agarose gel, blotted to a $\mathrm{N}^{+}$Nytran membrane, and hybridized first with ${ }^{32} \mathrm{P}$-labeled $A$. regius $\mathrm{MGP}$ cDNA and later with A. regius $\mathrm{BGP}$ cDNA as described in the Materials and Methods section. (A) Ethidium bromide staining of Ribosomal 28S and 18S; (B) ArMGP mRNA expression; (C) ArBGP mRNA expression; and (D) relative levels of expression of ArMGP (white bars) and ArBGP (black bars) in different tissues. Ethidium bromide staining of ribosomal RNA $18 \mathrm{~S}$ was used to determine the relative intensity of ArBGP and ArMGP gene expression measured as described in the Materials and Methods section. N.d., not detected.

myocardial fibers (striated cardiac muscle) and covered on the inner side with endothelial cells (Fig. 8B). Finally, the arteries of $S$. aurata, like the other teleost fishes, are composed of three layers: (1) intima (endothelial cells), (2) media (elastic fibers and smooth muscle cells), and (3) adventitia (loose connective tissue) (Fig. 8C). Specific sites of expression of the MGP gene in bulbus arteriosus were localized in endothelial cells and smooth muscle cells only (Fig. 8D). Results obtained in ventral aorta and myocardium are shown in Figs. 8F and 8H. These results indicate that the MGP gene is expressed in the intima and media layers from ventral aorta, mainly composed of endothelial and smooth muscle cells, respectively (Fig. 8F). On the contrary, there is no positive signal for ArMGP gene expression in the cardiac striated muscle fibers in the heart ventricle from $S$. aurata specimens (Fig. 8H). The control hybridization with sense ArMGP riboprobe showed no positive signal (Figs. 8E and $8 \mathrm{G})$.

Localization of specific sites of expression of the MGP gene in calcified structures was determined by in situ hybridization to confirm the results obtained by immunohistochemistry. In A. regius gill sections, using an antisense riboprobe specific for ArMGP mRNA, the presence of MGP message was detected within the cytoplasm of proliferating chondrocytes from the branchial filaments (Fig. 8I) and in

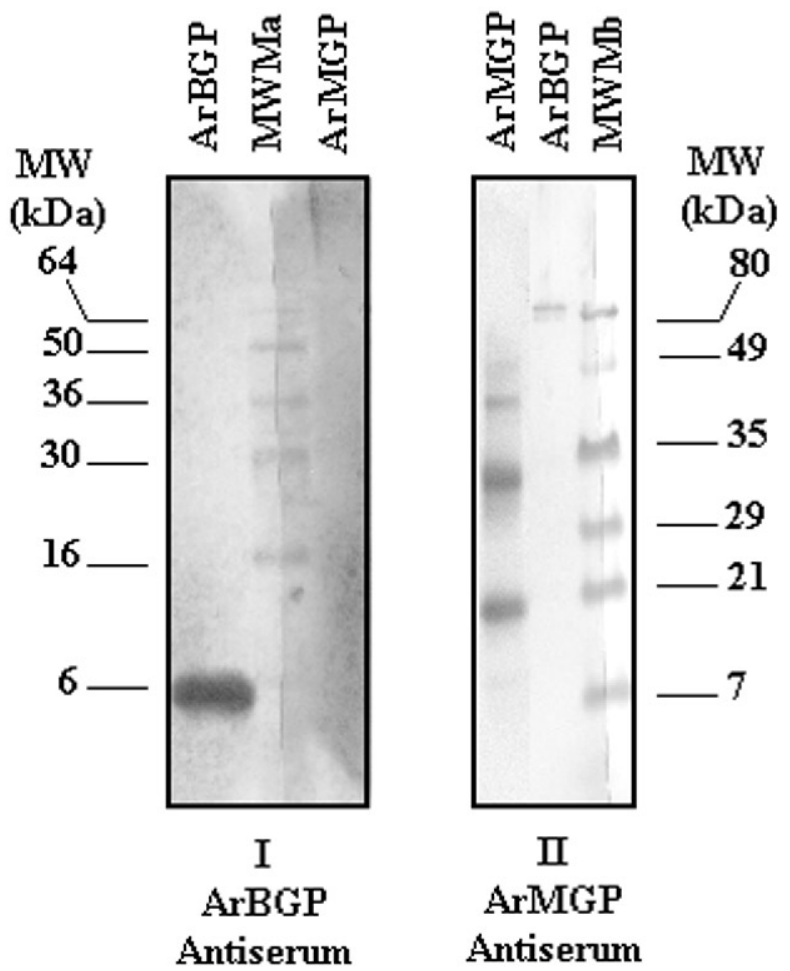

FIG. 6. Western blot analysis of ArMGP and ArBGP polyclonal antiserum. One microgram of each protein was electrophoresed on two $18 \%$ SDS-PAGE gels (Novex; Invitrogen). After electrophoresis, proteins were blotted onto nitrocellulose, and the membranes were either incubated with (I) 1:100 dilution of ArMGP antiserum or (II) 1:100 dilution of ArBGP antiserum. Alkaline phosphatase-labeled goat antirabbit IgG was used as secondary antibody and NBT/BCIP as substrate solution as described in the Materials and Methods section. MWMa, pre-stained molecular weight markers from Invitrogen; MWMb, prestained molecular weight markers from Bio-Rad.

mature chondrocytes included in the hyaline cartilage from the branchial arches (Fig. 8J).

\section{Effect of ArMGP on in vitro calcification assay}

The possibility that ArMGP can function as a calcification inhibitor was assessed using an in vitro assay previously developed for mammalian MGP. ${ }^{(27)}$ After addition of purified ArMGP to a serum solution containing elastin extracted from human aorta, ArMGP was able to inhibit calcium deposition in the elastin matrix as assessed by incorporation of ${ }^{45} \mathrm{Ca}$. This effect was dose dependent, and the inhibitory effect of ArMGP on calcium uptake by the aorta media elastin was indistinguishable from the effect observed with the purified bovine MGP protein in the same assay (Fig. 9).

\section{Evolution of MGP and BGP primary protein structure}

The amino acid sequence of the complete ArMGP is presented in Fig. 10 and compared with all other presently available complete protein sequences for MGP (i.e., from a cartilaginous fish, an amphibian, a bird, and six mammalian species). The sequences were aligned to give maximal homology. In ArMGP as in all other known MGPs, a sequence 

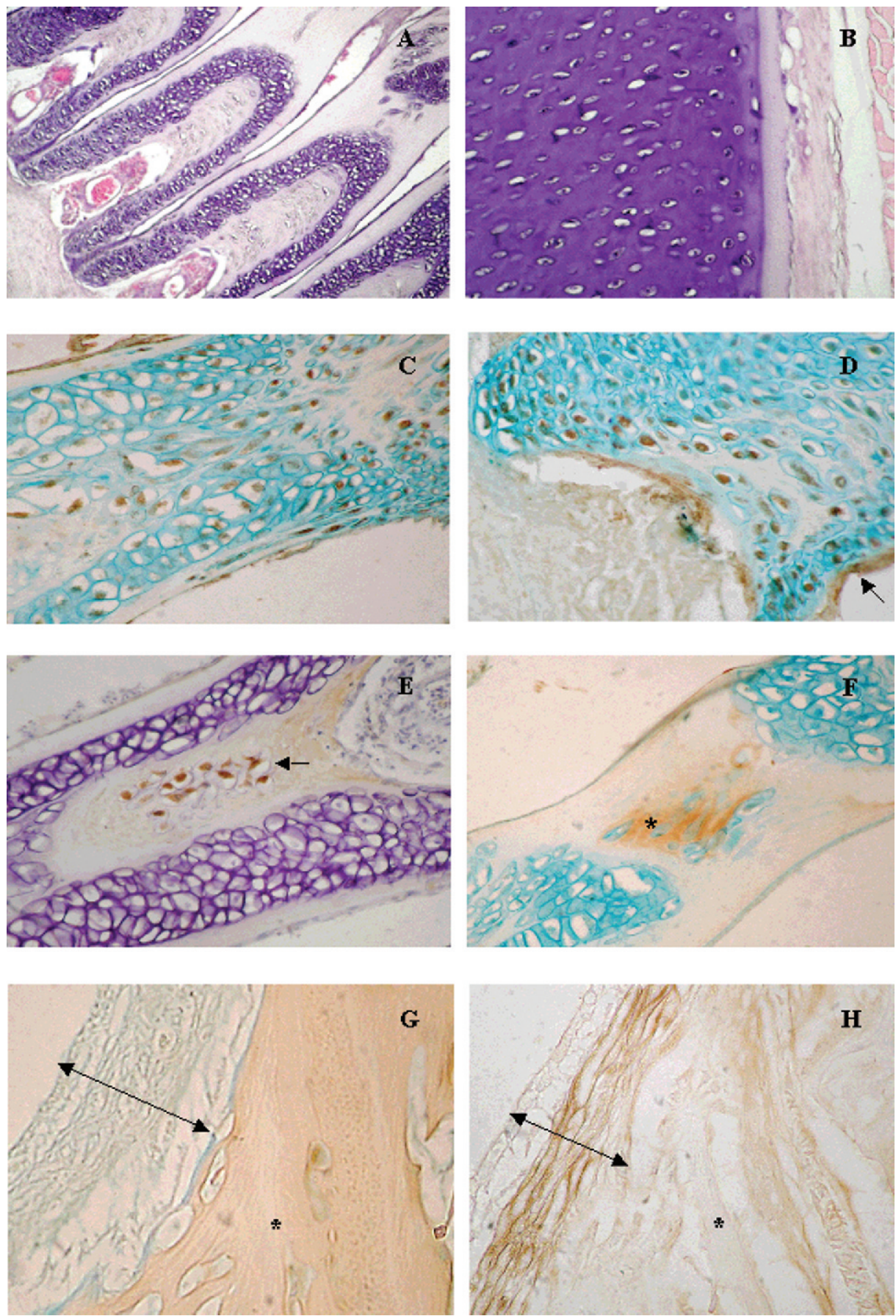

FIG. 7. Immunohistochemical distribution of MGP and BGP in calcified A. regius structures. Immunolabeling was performed in contiguous histological slides using both ArBGP and ArMGP antibodies. (A and B) Histological characterization of cartilage from branchial filaments. Proliferating chondrocytes in the (A) branchial filaments and branchial arches with mature chondrocytes immersed in a (B) hyaline matrix are easily recognized (hematoxylin/ eosin) $(\times 25$ and $\times 50$, respective1y). (C and D) MGP localization in branchial filaments as shown by positive peroxidase staining of MGP (in light brown). MGP is localized in proliferating and maturing chondrocytes cytoplasm $(\times 50)$ and in the calcifying front (arrow) surrounding the cartilage. Positive identification of the acid mucopolysaccharides of cartilage obtained by Alcian blue counter-staining (in blue). ( $\mathrm{E}$ and $\mathrm{F}$ ) BGP immunostaining in branchial filaments. Immunoreactive cells are located in the base of the branchial filaments, (E) outside the chondrocytecontaining zone (arrows) and (F) in the extracellular matrix in the medial zone of the branchial filaments (asterisk). Hematoxylin and Alcian blue counterstaining $(\times 50)$. ( $\mathrm{G}$ and $\mathrm{H})$ Comparison between BGP and MGP immunostaining in vertebra tissue from $A$. regius specimens. (G) BGP immunostaining is mainly located in the bony structure of the vertebra (asterisk). Note the absence of immunostaining in the zone comprising the neural arch, mainly composed of cartilage (double arrow; Alcian blue counterstaining $\times 25$ ). (H) On the contrary, MGP is mainly accumulated in the neural arch portion (double arrow), showing negative staining in the adjacent bony structures (asterisk). of 19 amino acid residues, corresponding to the expected signal peptide, precedes the first residue of the mature MGP protein and is rich in alanine and leucine (Fig. 10A), as previously shown for other signal peptides. ${ }^{(34)}$ The mature form of ArMGP, with 99 residues, shares with the shark sequence the presence of a C-terminal extension, not found in any of the other known non-fish MGPs (Xenopus, chicken, and all mammals analyzed). Amino acid residues 41-48 have no counterpart in any of the other known MGPs. Comparison between all known MGP sequences indicates that conserved motifs previously identified among all MGPs are also present in this teleost fish sequence. Phylogenetic analysis using the Treeview program ${ }^{(35)}$ positions ArMGP closer to shark than to all others MGPs (results not shown).

Comparison between ArBGP and other fish BGPs indicate that all mature fish sequences have in common 25 of a maximum of 47 amino acid residues, with the larger block of identity located between residues 9 and 18 of ArBGP (EXXXEXCEXXXXC motif, Fig. 11), a region that contains the three Gla residues and the two cysteines involved in the disulfide bridge. Interestingly, and as previously 

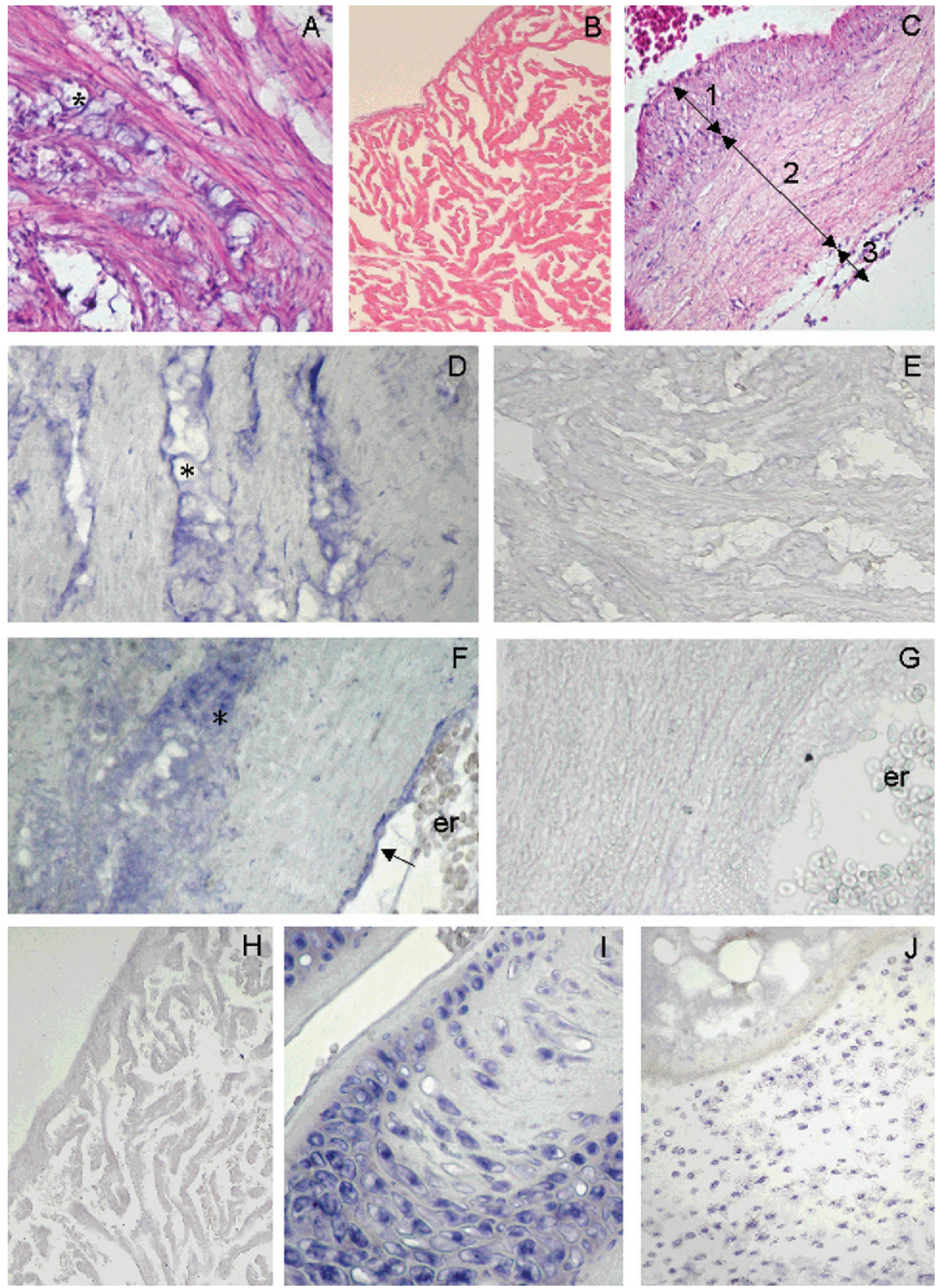

FIG. 8. Localization of ArMGP mRNA in cells within calcified tissues and vascular system by in situ hybridization. (A-C) Histological characterization of bulbus arteriosus $(\times 50)$, ventricle $(\times 25)$, and aortic wall $(\times 25)$, respectively. (A) The bulbus arteriosus wall is composed by elastic fibers and smooth muscle cells, stained in red-purple, and endothelial cells, stained in blue (asterisk; hematoxylin/eosin). (B) The ventricle from Sparus aurata specimens shows the spongy distribution of myocardial fibers (red-purple; hematoxylin/eosin $\times 50$ ). (C) In the aortic wall, three layers can be detected: (1) intima, (2) media, and (3) adventitia. (D and E) ArMGP mRNA in endothelial cells from bulbus arteriosus (asterisk) and in smooth muscle vascular cells. Note the absence of signal in the sense probe $(\mathrm{E})$ performed in adjacent slide $(\times 50)$. (F) Blue staining corresponding to the presence of ArMGP mRNA detected in the endothelia (arrow) and media layer (asterisk) from aortic wall: er, erythrocytes. (G) The sense probe did not reveal any positive signal: er, erythrocytes $(\times 50)$. Note the absence of signal for ArMGP mRNA $(\mathrm{H})$ in the ventricular structure $(\times 50)$. (I and J) Intense blue staining, corresponding to the presence of ArMGP mRNA was detected in chondrocytes, both in (I) branchial filaments $(\times 50)$ and $(\mathrm{J})$ hyaline cartilage from branchial arches $(\times 25)$ reported for Xenopus and chicken MGPs, ${ }^{(3)}$ A. regius MGP also shares the location of these three Gla residues with all BGPs, whereas only two are conserved in the mammalian MGP sequences (Figs. 10 and 11). The two cysteine residues involved in the disulfide bridge are $100 \%$ conserved in all known BGPs and MGPs.

\section{DISCUSSION}

In this paper, we describe the purification of MGP from a teleost fish, A.regius, and deduce its complete amino acid sequence from the cloned cDNA. The tissue distribution of MGP mRNA and sites of protein accumulation were determined by a combination of Northern and in situ hybridiza- tion analysis as well as immunohistochemistry using specific antibodies developed against the mature MGP protein. This is the first report on the complete cDNA and protein sequences for MGP from a marine teleost fish and provides important information toward understanding the evolution of MGP structure and function.

In contrast with previous results obtained in higher vertebrates $^{(1,2)}$ and Xenopus, ${ }^{(3)}$ we were unable to purify MGP from the bone tissue (vertebra and jaw) of any of the marine teleost fishes used. This result suggested that bone was not a major site of accumulation for MGP in teleost fish. Based on results previously obtained with a cartilaginous fish (shark), ${ }^{(22)}$ calcified cartilage from branchial arches of a 


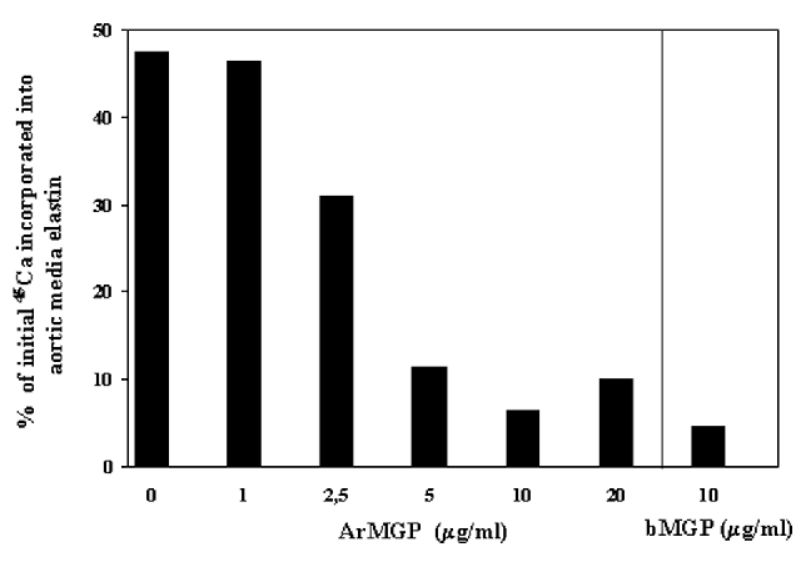

FIG. 9. Dose-dependent inhibition by MGP of calcium uptake by human elastin. Two milliliter aliquots of human heparinized plasma containing $2 \mathrm{mg}$ of base-treated human aortic media elastin, 800,000 CPM of ${ }^{45} \mathrm{Ca}, 0.02 \% \mathrm{NaN}_{3}$, and the indicated concentrations of added A. regius and bovine MGP were incubated at $37^{\circ} \mathrm{C}$ for 8 days. After 8 days, the elastin samples were removed from plasma and treated as described in the Materials and Methods section. The amount of ${ }^{45} \mathrm{Ca}$ incorporation was determined by measuring the radioactivity in $100 \mu \mathrm{l}$ of elastin acid extracts. Each point represents the average value obtained from two samples at each MGP concentration. bMGP, bovine MGP; ArMGP, A. regius MGP.

marine teleost fish (A. regius) was collected and analyzed for the presence of Gla-containing proteins of molecular weight comparable with that of shark MGP using a Glaspecific colorimetric assay. ${ }^{(23)}$ This strategy identified a 20-kDa Gla protein in branchial arches of $A$. regius that was then purified through a large-scale preparation, and its identity was confirmed by protein sequence analysis.

ArMGP was found to behave as expected throughout all the purification procedure, indicating that its physical properties were comparable with those of MGPs purified from all other vertebrates. Among the conserved features are (1) the typical phosphoserine-containing motif ESXESXESXE (amino acids 3-11) found in the N-terminal region of all known MGPs (shark, Xenopus, chicken, and mammals) ${ }^{(3)}$; (2) the presence of the ANSF motif (residues 20-23), previously identified as a conserved proteolytic cleavage site in mammalian and shark MGPs (PA Price, unpublished results, 1992); and (3) the core of the Gla-containing domain with the typical EXXXEXCXXXXXC motif (residues 5365 ), encompassing the two cysteines required for the formation of the disulfide bridge (Fig. 10).

Both the amphibian and the shark MGPs, as well as all the mammalian MGP sequences analyzed to date, have conserved phosphoserine residues at sequence positions 3,6 , and 9. ${ }^{(2,3)}$ Because phosphoserine residues will give blanks under normal sequence analysis conditions ${ }^{(36)}$ and the initial sequence analysis of the ArMGP protein did not result in blanks at positions 3, 6, and 9 (Table 1), the levels of serine phosphorylation were determined, confirming that a mixture of serine and S-propylcysteine was found at each of the three possible sites for phosphorylation (residues 3, 6, and 9). This result showed that all three serines were partially phosphorylated. In addition, a fourth serine (residue 7 of the mature protein, Fig. 10) was also shown to be phosphory- lated. Because ArMGP is the only known MGP with a serine residue at this position, the presence or absence of phosphorylation at this particular site cannot be compared with other MGPs.

In contrast with all other known MGPs, ArMGP has only four possible Gla residues, located at positions 2, 53, 57, and 60. Glutamic acid residues at positions 2 and 57 correspond to conserved Gla sites among all MGPs, whereas Gla at position 60 is found in fish, ${ }^{(31,32,37)}$ as well as in Xenopus and chicken MGPs, ${ }^{(3)}$ but is not present in mammalian MGPs. This site also shares homology with a site of $\gamma$-carboxylation present in all known BGPs, ${ }^{(3)}$ reinforcing the hypothesis that both proteins are derived from a common ancestor. ${ }^{(3,31)}$

Comparison of SDS-PAGE migration profiles of fish MGP with that of bovine MGP suggested that the protein sequence of ArMGP was longer than that of known Xenopus and mammalian MGPs. This result was confirmed once we obtained the complete cDNA and deduced the sequence of the entire ArMGP protein. The presence of one internal insertion in $A$. regius versus all known MGPs (residues 41-48, Fig. 10) and a C-terminal extension only previously seen in shark MGP (Fig. 10) accounted for the different migration profile and apparent size difference originally detected between fish and bovine MGP (Fig. 2). This C-terminal extension has not been conserved in MGPs from amphibians, birds, or higher vertebrates, and its function in fish remains to be elucidated.

In the course of the final Sephacryl S-100 purification, we also obtained a small peak thought to correspond to ArBGP by N-terminal protein sequence analysis (Fig. 1; Table 1), a result later confirmed by Northern analysis (Fig. 5). This protein sequence was also identical to the one obtained from vertebra as deduced from its cDNA (Fig. 4). This finding indicated that BGP was also present in branchial arches, in the calcified region of the primary arches, a result also confirmed by immunohistochemistry (Fig. 7). The characterization of this bone-like mineralized extracellular matrix by in situ hybridization and immunohistochemistry will be the subject of future studies once additional specific molecular markers are available for this fish. BGP was also purified from $A$. regius vertebra but with a higher yield, as expected, because fish bone has previously been shown to accumulate BGP at levels comparable with those seen in mammalian bone. ${ }^{(31)}$

After the cloning of ArMGP cDNA, tissue distribution of MGP mRNA was determined by Northern blot analysis. In mineralized tissues, MGP mRNA was present in calcified cartilage and also in vertebra (no effort was made to remove all cartilage surrounding bone tissue), whereas in soft tissues, heart was by far the major site of MGP gene expression (Fig. 5). In situ hybridization analysis permitted to clearly identify in which cells the MGP gene was being transcribed. These results clearly showed that in branchial arches, MGP mRNA was present uniquely in chondrocytes and that the positive signal obtained for vertebra by Northern analysis was because of the presence of MGPexpressing chondrocytes located in the cartilaginous layer (Alcian blue-positive) located at the periphery of bone tissue (Figs. $7 \mathrm{G}$ and $7 \mathrm{H}$ ). The same technique permitted to put 
A

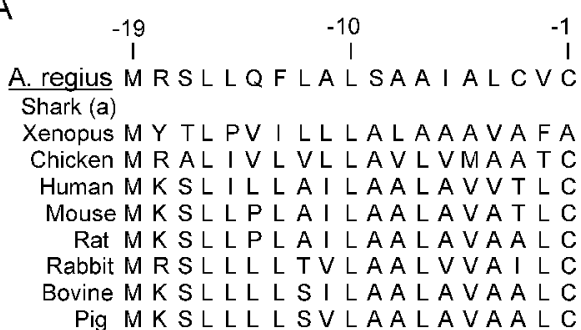

B

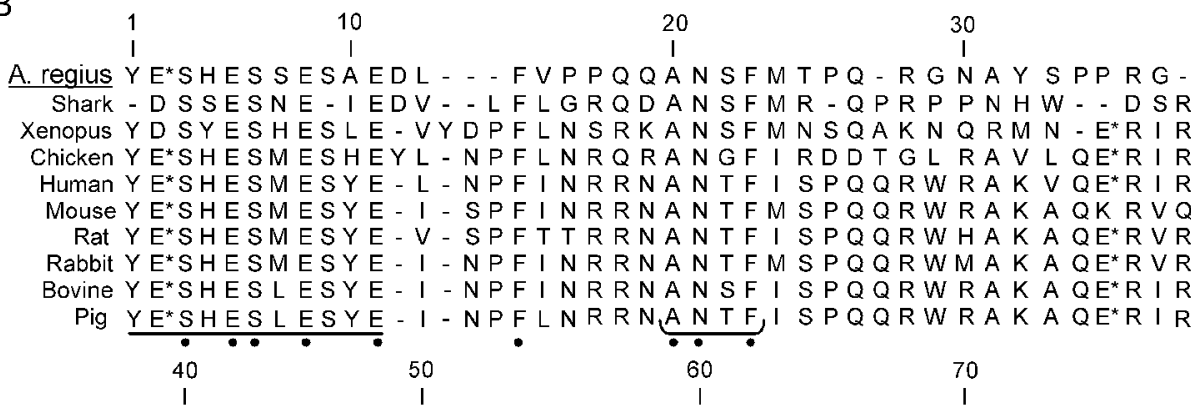

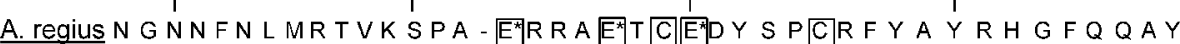

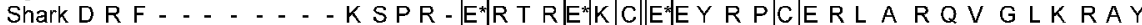
Xenopus $E^{*} R N \ldots \ldots$....... K SPR - E* R Q R E* A C E E Chicken $E^{*} R N$ - . - . - K K PQ - E*RQR E* I C E*D F H L C E Q Y A L N H G Y P A A Y

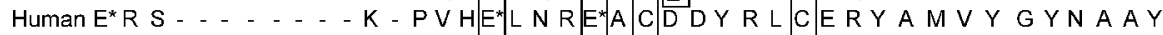

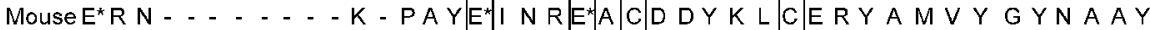

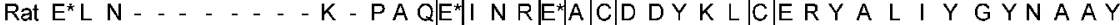

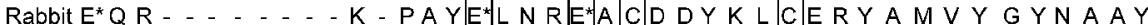

Bovine $E^{*} L N \ldots \ldots$....... K - PQY E* $L$ N R E* A C D D F K L C E R Y A M V Y G Y N A A Y

Pig $E^{*} L N \ldots$ 80 90

I

A. regius $Q R Y F G S--G T H P Q Q--R P A A A A-R R Y$

Shark GK YF GNRRQRPSTSGRLRP RKYRASRYRNH

Xenopus K R YF GQRRGE KK

Chicken R H YF GRRRN - K

Human N R Y F RKRRGT K

Mouse NR YF RQRRGAKY

Rat N R YF RQRRGA K

Rabbit N R YF RQRRRAE

Bovine D R YF RQRRGAK

Pig NRYFRQRPGAK

.
FIG. 10. Comparison of A. regius MGP amino acid sequence with other known MGPs from a cartilaginous fish, an amphibian, a bird, and mammals. (A) Signal peptide amino acid sequences deduced from corresponding cDNA. (B) Mature protein amino acid sequences obtained by protein sequence analysis and/or cDNA sequence. The sequences are aligned to give maximal homology and conserved residues are marked by a dot. Dashes indicated gaps in the sequence, introduced to increase homology. Residues are numbered according to residue 1 of mature $A$. regius MGP. Residues 53, 57, and 60 in ArMGP are presumed to be carboxylated based on homology with other MGPs. $\gamma$-Carboxyglutamate residues are indicated by $\left(\mathrm{E}^{*}\right)$. The Gla-containing domain is underlined with a noncontinuous line and the conserved residues in the EXXXEXCXXXXXC motif are boxed. The conserved proteolytic cleavage site ANSF motif is indicated with a bracket. Phosphoserine-containing motif ESXESXESXE is underlined. Sequence GenBank accession numbers are as follows: AF334473 for A. regius; P56620 for shark (G. galeus); $\mathrm{AF} 055588$ for Xenopus (X. laevis); Y13903 for chicken (Gallus gallus); NM012862.1 for rat (Rattus norvegicus); AF210379 for bovine (Bos taurus); BC005272 for human (Homo sapiens); NM008597 for mouse (Mus musculus); D21265 for rabbit (Oryctolagus cuniculus); and AF525316 for pig (Sus scrofa), (a) Sequence not available.

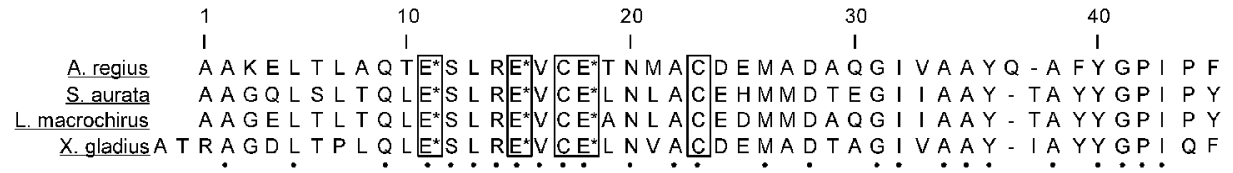

FIG. 11. Comparison between A. regius BGP amino acid sequence with other known fish BGPs. Residues 11 , 15 , and 18 in ArBGP are presumed to be carboxylated based on homology with other BGPs. $\gamma$-Carboxyglutamate residues are indicated by (E*). The sequences are aligned to give maximal homology and conserved residues are marked by a dot. Residues are numbered according to residue 1 of mature $A$. regius BGP. The conserved residues in the EXXXEXCXXXXXC motif are boxed. Sequence GenBank accession numbers are as follows: AF459030 for A. regius; AF048703 for S. aurata (Seabream); A42794 for Lepomis macrochirus (bluegill); and P02823 for Xiphias gladius (Swordfish).

in evidence, using a similar system (the seabream Sparus aurata, another marine teleost fish that can be grown in captivity and that also expresses the MGP gene in whole heart tissue; ML Cancela, unpublished results, 2002), that only few cell types within specific compartments of the cardiac structure were actively transcribing the MGP gene. These results provided clear evidence that only smooth muscle cells and endothelial cells within the arterial wall and the bulbus arteriosus were responsible for the previously encountered high levels of MGP mRNA in whole heart extracts by Northern analysis, whereas no MGP mRNA was detected in those sites consisting predominantly of striated muscle fibers (such as the ventricle). The presence of MGP mRNA in cells within the arterial wall may also be responsible, at least in part, by the detected levels of this mRNA in other highly irrigated soft tissues such as 
kidney from fish, as well as from Xenopus $^{(3)}$ and from rat. ${ }^{(14)}$ These results are in general agreement with those previously obtained in mouse by similar techniques ${ }^{(16)}$ and are further evidence that smooth muscle and endothelial cells in fish, as in mammals, must play an important role in the protection of the vascular system against ectopic calcification. Accordingly, our preliminary results already indicate that in vivo treatment of marine fish with warfarin rapidly leads to an extended calcification in the vascular system (ML Cancela and PJ Gavaia, unpublished results, 2002).

Although tissue distribution of MGP mRNA in fish parallels that seen in mammals ${ }^{(14,16)}$ and in amphibians, ${ }^{(3)}$ the MGP protein did not accumulate at significant levels in vertebra of the different fishes analyzed, possibly because of the reported acellular nature of their bone, in contrast with findings in mammals, birds, and amphibians. This result was unexpected and made purification of fish MGP more difficult than anticipated. Immunohistochemical detection of MGP in fish tissues confirmed that it accumulated mainly in the extracellular matrix of mineralized cartilage, in regions undergoing or immediately adjacent to mineralization fronts (Fig. 7). These results are in agreement with the previously reported accumulation of MGP in shark vertebra, ${ }^{(22)}$ which is made of calcified cartilage and not bone, ${ }^{(38)}$ as well as with the results previously obtained in mammals. ${ }^{(13)}$ Our results further suggest that MGP may have originally accumulated only in the extracellular matrix of mineralized cartilage and that its trapping in bone tissue may be secondary to the appearance, throughout evolution, of a more elaborate bone structure found in terrestrial vertebrates. These results provide a possible explanation for the different pattern of MGP accumulation observed in calcified tissues (cartilage or bone) in the marine teleost fishes studied and other vertebrates. Our results also indicate that fish MGP, like mammalian MGP, probably functions in vivo as a calcification inhibitor. ArMGP was capable of inhibiting calcium uptake by the extracellular matrix in an in vitro calcification assay, at concentrations comparable with those seen with bovine MGP. These results suggest, altogether, that the role played by MGP as a protector against abnormal and ectopic calcification could be a feature conserved from fish to mammals. Furthermore, it is likely that to maintain its function has required a conserved three-dimensional structure of the protein and the maintenance of its physical properties. This may have been the reason why a number of amino acid residues presumably important for the folding of the protein have been $100 \%$ conserved at a particular site of the protein over more than 400 million years of evolution. This could be the case for the invariable glycine at position 73 , usually positioned at sites of rotation or the two cysteines required for the disulfide bridge (see Fig. 10).

Taken together, our results provide clear evidence that the fish is not only an adequate model to further analyze the mode of action and function of MGP at the molecular level, but can also bring invaluable information for better understanding the evolutionary reasons that have led to the maintenance of some particular residues or motifs of the MGP protein and not others throughout vertebrate evolution.

\section{ACKNOWLEDGMENTS}

This work was supported in part by research grants from PRAXIS (BIA/2.1/469/94 and 11159/98), NATO (CRG 940751), and the U.S. Public Health Service (AR25921). DCS, JBO, and CSBV were the recipients, respectively, of a $\mathrm{PhD}$ grant financed by PRODEP 5.2 program from the Portuguese Ministry of Education, a postdoctoral fellowship (SFRH/BPD/7151/2001) from the Portuguese Science and Technology Foundation (FCT), and of a FCT Research fellowship (PRAXIS XXI/BIC/22320/99). We thank F Alagao for doing the in vitro calcification assay and $\mathrm{R}$ Leite for helpful assistance in the preparation of the figures.

\section{REFERENCES}

1. Price PA, Williamson MK 1985 Primary structure of bovine matrix Gla protein, a new vitamin K-dependent bone protein. J Biol Chem 260:14971-14975.

2. Price PA, Rice JS, Williamson MK 1994 Conserved phosphorylation of serine in the Ser-X-glu/Ser(P) sequences of the vitamin K-dependent matrix Gla protein from shark, lamb, rat, cow and human. Protein Sci 3:822-830.

3. Cancela ML, Williamson MK, Ohresser MCP, Reia JP, Price PA 2001 Matrix Gla protein in Xenopus laevis: molecular cloning, tissue distribution and evolutionary considerations. J Bone Miner Res 16:1611-1622.

4. Hale JE, Fraser JD, Price PA 1988 The identification of matrix Gla protein in cartilage. J Biol Chem 263:5820-5824.

5. Price PA, Faus SA, Williamson MK 1998 Warfarin causes rapid calcification of the elastic lamellae in rat arteries and heart valves. Arterioscler Thromb Vasc Biol 18:1400-1407.

6. Wallin R, Cain D, Sane DC 1999 Matrix Gla protein synthesis and gamma-carboxylation in the aortic vessel wall and proliferating vascular smooth muscle cells. Thromb Haemost 82:1764-1767.

7. Price PA, Faus SA, Williamson MK 2000 Warfarin-induced artery calcification is accelerated by growth and vitamin D. Arterioscler Thromb Vasc Biol 20:317-327.

8. Shanahan CM, Proudfoot D, Tyson KL, Cary NRB, Edmonds M, Weissberg PL 2000 Expression of mineralization-regulating proteins in association with human vascular calcification. Z. Kardiol 89(Suppl 2):63-68.

9. Spronk HMH, Soute BAM, Schurgers LJ, Cleutjens JPM, Thijssen HHW, De Mey JGR, Vermeer C 2001 Matrix Gla protein accumulates at the border of regions of calcification and normal tissue in the media of the arterial vessel wall. Biochem Biophys Res Commun 289:485-490.

10. Fraser JD, Otawara Y, Price PA 1988 1,25-Dihydroxyvitamin D3 stimulates the synthesis of matrix $\gamma$-carboxyglutamic acid protein by osteosarcoma cells. J Biol Chem 263:911-916.

11. Cancela ML, Price PA 1992 Retinoic acid induces matrix Gla protein gene expression in human cells. Endocrinology 130:102108.

12. Cancela ML, Hu B, Price PA 1997 Effect of cell density and growth factors on matrix Gla protein expression by normal rat kidney cells. J Cell Physiol 171:125-134.

13. Luo G, D‘Souza R, Hogue D, Karsenty G 1995 The matrix Gla protein is a marker of the chondrogenesis cell lineage during mouse development. J Bone Miner Res 10:325-334.

14. Fraser JD, Price PA 1988 Lung, heart and kidney express high levels of mRNA for the vitamin K-dependent matrix Gla protein. J Biol Chem 263:11033-11036.

15. Price PA, Williamson MK, Haba T, Dell RB, Jee WSS 1982 Excessive mineralization with growth plate closure in rats on chronic warfarin treatment. Proc Natl Acad Sci USA 79:77347738 .

16. Luo G, Ducy P, McKee MD, Pinero GJ, Loyer E, Behringer RR, Karsenty G 1997 Spontaneous calcification of arteries and cartilage in mice lacking matrix Gla protein. Nature 386:78-81.

17. Howe AM, Webster WS 2000 Warfarin exposure and calcification of the arterial system in the rat. Int J Exp Pathol 81:51-56.

18. Weiss RE, Watabe N 1979 Studies on the biology of fish bone. III. Ultrastructure of osteogenesis and resorption in osteocytic (cellular) and anosteocytic (acellular) bones. Calcif Tissue Int 28:43-56. 
19. Witten PE, Villwock W 1997 Growth requires bone resorption at particular skeletal elements in a teleost fish with acellular bone (Oreochromis niloticus, Teleostei: Cichlidae). J Appl Ichthyol 13:149-158.

20. Witten PE 1997 Enzyme histochemical characteristics of osteoblasts and mononucleated osteoclasts in a teleost fish with acellular bone (Oreochromis niloticus, Cichlidae). Cell Tissue Res 287: 591-599.

21. Taylor WR, Van Dyke C 1985 Revised procedures for staining and clearing small fishes and other vertebrates for bone and cartilage study. Cybium 9:107-119.

22. Rice JS, Williamson MK, Price PA 1994 Isolation and sequence of the vitamin K-dependent matrix Gla protein from the calcified cartilage of the soupfin shark. J Bone Miner Res 9:567-576.

23. Jie K-SG, Gijsbers BLMG, Vermeer C 1995 A specific colorimetric staining method for $\gamma$-carboxyglutamic acid-containing proteins in polyacrylamide gels. Anal Biochem 224:163-165.

24. Meyer HE, Hoffmann-Posorske E, Heilmeyer LMG 1991 Determination and location of phosphoserine in proteins and peptides by conversion to S-ethylcysteine. Methods Enzymol 201:169-185.

25. Otawara Y, Price PA 1986 Developmental appearance of matrix Gla protein during calcification in the rat. J Biol Chem 261:1082810832.

26. Sambrook J, Fritsch EF, Maniatis T 1989 Molecular Cloning: A Laboratory Manual, 2nd ed. Cold Spring Harbor Laboratory Press, New York, NY, USA.

27. Alagao FC, Patel R, Price PA 2000 Matrix Gla protein specifically inhibits calcification of human aortic elastin in vitro. J Bone Miner Res 15:S1;S208.

28. Sarasquete C, Muñoz-Cueto JA, Ortiz JB, Rodrigues-Gómez FJ, Dinis MT, Segner H 1999 Immunocytochemical distribution of cytocrome P4501A(CYP1A) in developing gilthead seabream, Sparus aurata. Histol Histopathol 14:407-415.

29. Arellano JM, Storch V, Sarasquete C 2001 A histological and histochemical study of the oesophagus and oesogaster of the Senegal sole, Solea senegalensis. Eur J Histochem 45:279-294.

30. Pinto JP, Ohresser MCP, Cancela ML 2001 Cloning of the bone Gla protein gene from the teleost fish Sparus aurata. Evidence for overall conservation in molecular structure and pattern of expression from fish to man. Gene 270:77-91.

31. Cancela ML, Williamson MK, Price PA 1995 Amino-acid sequence of bone Gla protein from the African clawed toad Xenopus laevis and the fish Sparus aurata.. Int J Peptide Protein Res 46:419-423.

32. Nishimoto SK, Araki N, Robinson FD, Waite JH 1992 Discovery of bone $\gamma$-carboxyglutamic acid protein in mineralized scales. The abundance and structure of Lepomis macrochirus bone $\gamma$-carboxyglutamic acid. J Biol Chem 267:11600-11605.

33. Brown ME 1957 Cardiovascular system. In: Hoar VS., Randall DJ. (eds) The Physiology of Fishes, vol. I. Academic Press, New York, NY, USA, pp. 7-252.

34. Heijne G 1984 How signal sequences maintain cleavage specificity. J Mol Biol 173:243-251.

35. Page RDM 1996 TREEVIEW: An application to display phylogenetic trees on personal computers. Comp Appl Biosci 12:357-358.

36. Meyer HE, Hoffmann-Posorske E, Korte H, Heilmeyer LMG 1986 Sequence analysis of phosphoserine containing peptides. FEBS Lett 204:61-66.

37. Price PA, Otsuka AS, Poser JW 1977 Comparison of gammacarboxyglutamic acid-containing proteins from bovine and swordfish bone: Primary structure and $\mathrm{Ca}^{2+}$ binding. In: Wasserman $\mathrm{RH}$, Corradino RA, Carafoli E, Kretsinger RH, Mac-Lennan DH, Siegel FL (eds.) Calcium Binding Proteins and Calcium Function. Elsevier North-Holland, Amsterdam, The Netherlands, pp. 333337.

38. Clement JG 1992 Re-examination of the fine structure of endoskeletal mineralization in chondrichthyans: Implications for growth, aging and calcium homeostasis. Austr J Marine Freshwater Res 43: $157-181$.

\author{
Address reprint requests to: \\ $M$ Leonor Cancela, PhD \\ Center for Marine Sciences-CCMar \\ University of Algarve \\ Campus de Gambelas \\ 8000-810 Faro, Portugal \\ E-mail: lcancela@ualg.pt
}

Received in original form February 8, 2002; in revised form August 13, 2002; accepted September 11, 2002. 